\title{
My father didn't think this way': Nigerian boys contemplate gender equality
}

Françoise Girard

Follow this and additional works at: https://knowledgecommons.popcouncil.org/departments_sbsr-pgy

Part of the Family, Life Course, and Society Commons, Gender and Sexuality Commons, International Public Health Commons, and the Public Health Education and Promotion Commons How does access to this work benefit you? Let us know!

\section{Recommended Citation}

Girard, Françoise. 2003. "'My father didn't think this way': Nigerian boys contemplate gender equality," Quality/Calidad/Qualité no. 14. New York: Population Council. 
“My Father Didn't

Think This Way":

Nigerian Boys Contemplate Gender Equality
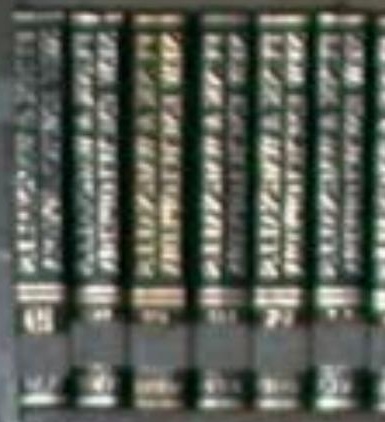


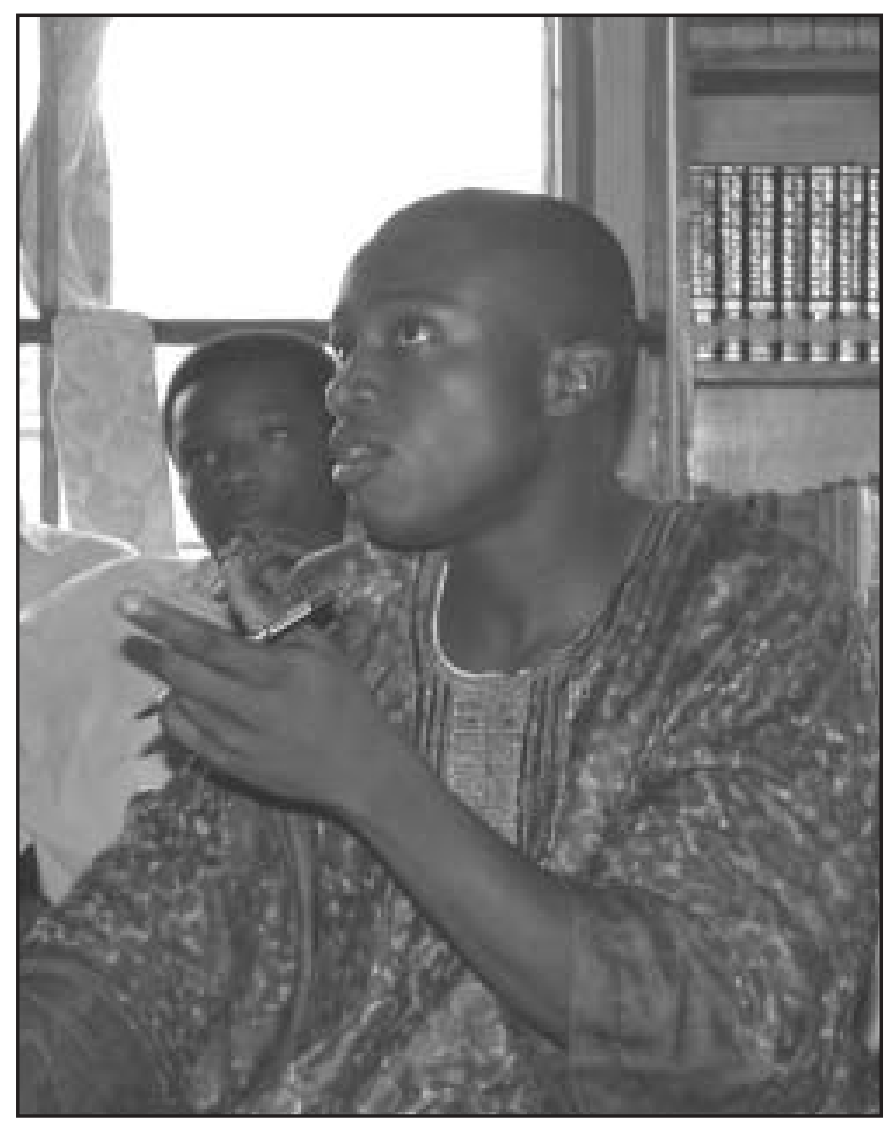

“My Father Didn't Think This Way": Nigerian Boys Contemplate Gender Equality 
Quality/Calidad/Q ualité, a publication of the Population Council, highlights examples of clinical and educational programs that bring a strong commitment, as well as innovative and thoughtful approaches, to the issue of high-quality care in sexual and reproductive health. The series is based on the philosophy that people have a fundamental right to respectful treatment, information, choice, and follow-up from reproductive health-care providers.

$\mathrm{Q} / \mathrm{C} / \mathrm{Q}$ documents projects that are making important strides in one or more of the following ways: broadening the choice of methods and technologies available; providing the information clients need to make informed choices; enabling clients to become more effective guardians of their sexual and reproductive health; making innovative efforts to increase the management capacity and broaden the skills of service providers at all levels; combining health care, family planning, and related services in innovative ways; and reaching underserved and disadvantaged groups.
Projects are selected for documentation by an advisory group made up of individuals who have a broad range of experience with promoting quality of care in sexual and reproductive health. None of the projects documented is being offered as a model for replication. Rather, each is presented as an unusually creative example of values, objectives, and implementation. These are learning experiences that demonstrate the selfcritical attitude required to anticipate clients' needs and find affordable means to meet them. This reflective posture is exemplified by a willingness to respond to changes in clients' needs as well as to the broader social and economic transformations affecting societies. Documenting the critical choices these programs have made should help to reinforce, in practical terms, the belief that an individual's satisfaction with sexual and reproductive health services is strongly related to the achievement of broader health and population goals.

Publication of this edition of Quality/Calidad/Q ualité is made possible by support provided by the International Women's Health Coalition, the Ford Foundation, and by the Gender, Family, and Development Program of the Population Council. Statements made and views expressed in this publication are solely the responsibility of the authors and not of any organization providing support for $Q / C / Q$. Any part of this document may be reproduced without permission of the authors so long as it is not sold for profit.

The International Women's Health Coalition works to generate health and population policies, programs, and funding that promote and protect the rights and health of girls and women worldwide, particularly in Africa, Asia, Latin America, and countries in postsocialist transition.

\section{Population Council}

The Population Council is an international, nonprofit, nongovernmental organization that seeks to improve the well-being and reproductive health of current and future generations around the world and to help achieve a humane, equitable, and sustainable balance between people and resources. The Council conducts biomedical, social science, and public health research and helps build research capacities in developing countries. Established in 1952, the Council is governed by an international board of trustees. Its $\mathrm{N}$ ew York headquarters supports a global netw ork of regional and country offices.

Population Council, O ne Dag Hammarskjold Plaza, New York, N ew York 10017 U SA

tel: (212) 339-0500 fax: (212) 755-6052 e-mail:qcq@popcouncil.org http://www.popcouncil.org

Cover photograph by Corinne Whitaker. The photograph on page 2 was selected from M/MC Photoshare at www.jhuccp.org/mmc.

Issue N o. 14 ISSN : 1097-8194

Copyright $\odot 2003$ The Population Council, Inc. 
by $\mathbf{G}$ ary Barker

The population and family planning field began paying attention to "male involvement" in the 1980s, primarily because men were often the decisionmakers regarding family size and contraceptive use. An inescapable lesson learned from two decades of fighting sexual violence and HIV, however, was that men are also frequently the decisionmakers about whether-and under what conditionswomen and girls will have sex. Gradually, program planners, international development organizations, and researchers came to understand that gender inequities-in sexual relationships, domestic life, and in society more broadly-are a root cause of poor sexual and reproductive health outcomes among men and women. By 1994, delegates from 180 countries met in Cairo at the International Conference on Population and Development and affirmed that men must be included in efforts to improve not only the reproductive health of women but also the social and legal status of women and girls worldwide (U nited Nations 1995).

A number of programs aimed at males are focusing most intensely on adolescent boys, rather than adult men. One rationale is that adolescent boys have particular needs. Many are struggling to continue or succeed in school, find employment, or provide financially for themselves and their families. OIder adolescent males are going through the phase of life in which they face the risk of acquiring sexually transmitted diseases (including HIV) and the risks related to violence. For example, mortality rates for young men aged 15-24 are between two and five times the rates of young women of the same age range, and significantly higher than the rates for adult men; the majority of these premature deaths are due to homicide and traf-

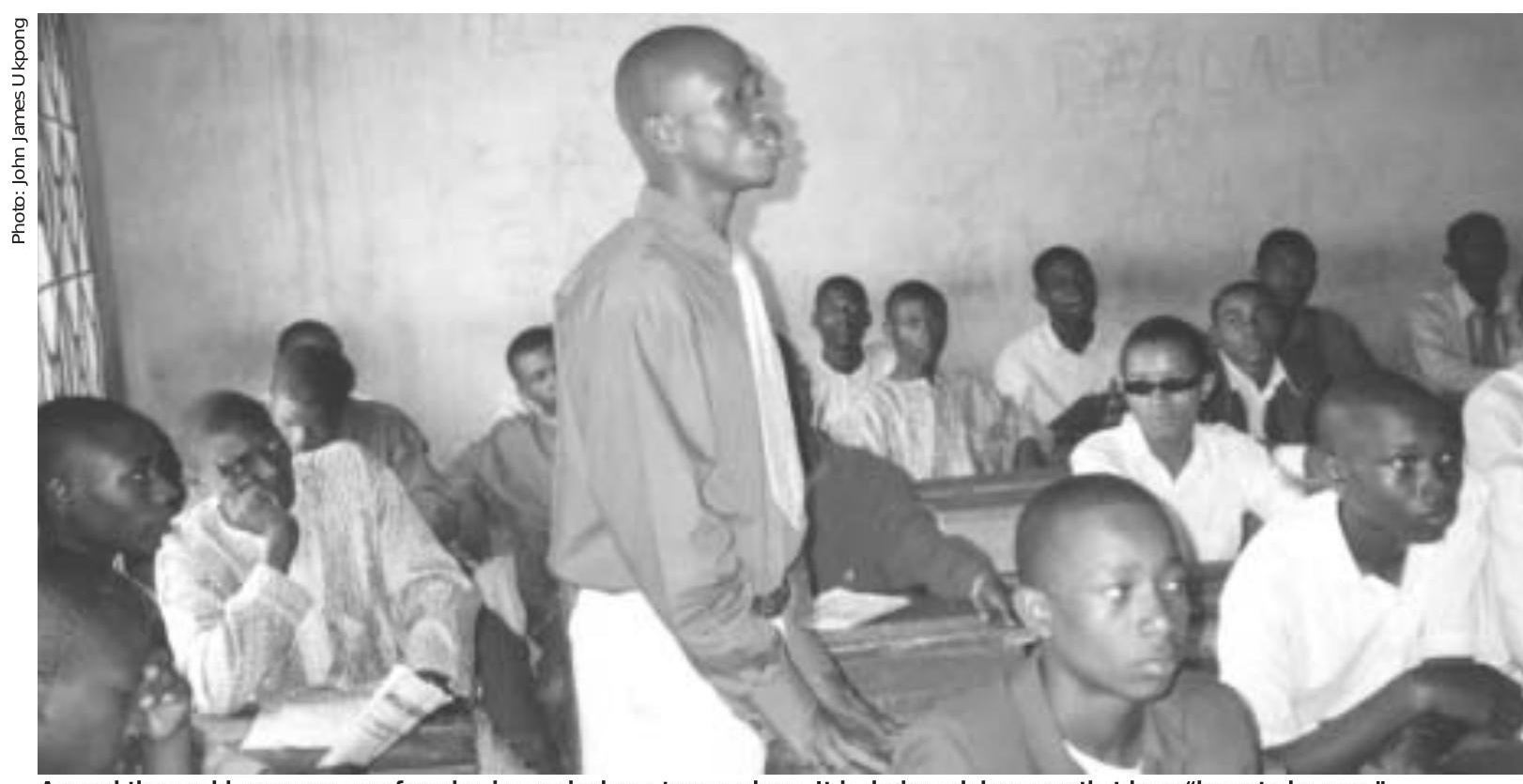

Around the world, programs are focusing increasingly on teenage boys. It is during adolescence that boys "learn to be men," to absorb and internalize the roles and the style of interaction in intimate relationships that they are likely to carry through their adult lives. 
fic accidents (Barker 2000). Another rationale for making programs for adolescent males a priority is that during their teenage years boys learn to be men, to absorb and internalize the roles and the style of interaction in intimate relationships that they are likely to carry through their adult lives.

Cultures and families almost universally promote a type of masculinity that is achievement-oriented and outwardly

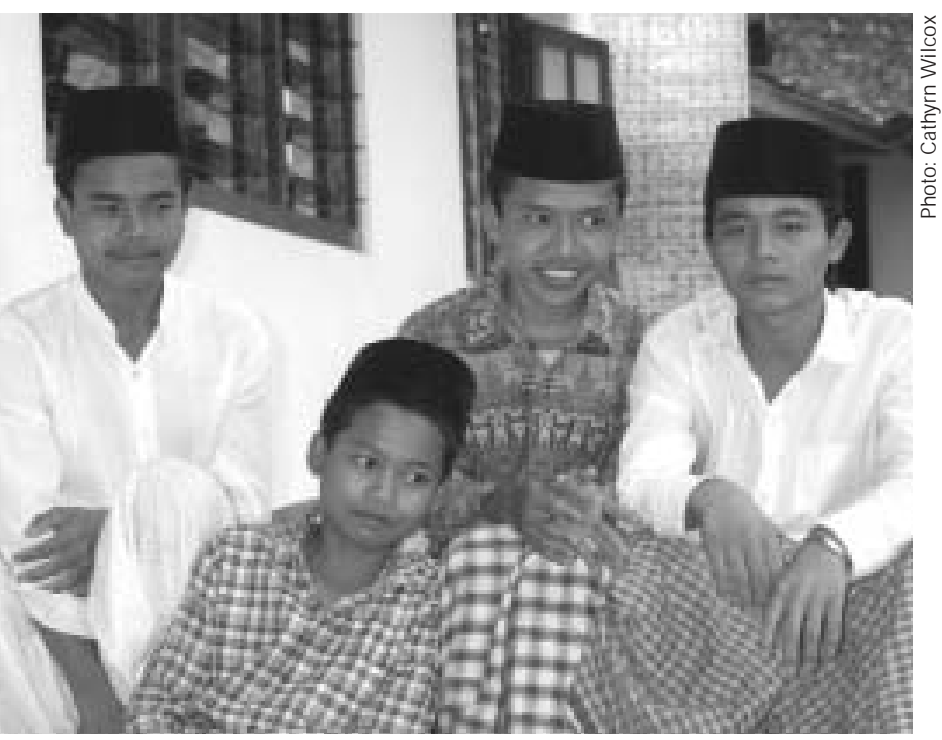

0 ne of the lessons emerging from adolescent programs around the world is the need to create settings where young men can question things that are often seen as unquestionable, such as what it means to be a man.

directed with the goal that boys should become providers and protectors (Gilmore 1990). Indeed, in many parts of the world, from an early age, boys generally spend more time on the street or outside the home in unsupervised circumstances than do girls, who are often forced during adolescence into social isolation and exclusion (Barker 2000). Male family circles and the male peer group provide the places where boys and young men "try out and rehearse macho roles" (Mosher and Tomkins 1988). M any young boys are socialized to be aggressive, violent, and competitive, characteristics considered useful for providers and protectors, whereas girls learn to be nonviolent and sometimes passive in accepting male violence and male sexual initiative (Archer 1984). Boys may be brought up to adhere to rigid codes of honor and courage that obligate them to compete, fight, and rely on violence, even in minor altercations (Archer 1994). Many boys come to see sex in these terms as well, they learn to view girls and women as objects for their sexual pleasure, to use force to obtain sex, and to view sex as performance. As part of establishing their masculinity, young men in most of the world must also signal that they are heterosexual or face enormous social stigma and isolation. Homophobia is used to force young men (both heterosexuals and those who are attracted to other males) to conform. For these reasons, boys prove their manhood in part by telling their peers about "getting" sex with girls.

If male peer groups are instrumental in constructing negative traditional versions of manhood, they can also be part of deconstructing these harmful aspects of gender. Indeed, given the opportunity, boys are able to identify the costs of trying to succeed in or live up to traditional masculine roles. Moreover, several studies have found that, for some young men, reflecting on their exposure to negative forms of male behavior such as their fathers' use of violence becomes a powerful pathway to change (Barker 2001). If boys learn to be respectful of their partners and to practice safer sexual activity, they often continue this behavior into adulthood. For example, a study in the United States found that adolescent males who used condoms during their first sexual relations were more likely to use condoms consistently thereafter (Sonenstein et al. 1995).

These findings suggest the need to work with young men earlier rather than later. Thus, after years of being 
admonished to "start earlier," a growing number of organizations worldwide have devised programs engaging younger boys on issues of sexual health and gender. The growth spurt and physiological maturation associated with puberty brings with it enhanced potential for critical thinking and abstract thought, including analyzing and reflecting about justice issues. A 1999 review conducted for the World Health Organization consulted 77 programs, governmental and nongovernmental, reaching boys and young men in schools, communities, workplaces, military facilities, and juvenile justice centers (Barker 2000). Their activities include, for example, offering boys-only hours at health centers; connecting boys with mentors who are positive male role models; providing vocational training; and conducting sexual health outreach. The majority of programs work in boys-only groups for some themes, while bringing boys and girls together to discuss gender-based inequality. Some programs, such as the W hite Ribbon Campaign, an international campaign of men working to end violence against women, seek to include both boys and adult men.

A number of lessons are emerging from this review and from case studies conducted in greater depth. Broadly speaking, programmatic experiences are generating a series of priorities: identifying boys' own rationale for change; engaging relatively few young men intensively in small groups over an extended period; tapping into the positive power of male peer groups to encourage gender equity; addressing homophobia; planning high-energy activities that involve multiple themes; working with boys on self-care and prevention; and creating settings where young men can talk openly about their doubts and question issues that are often seen as unquestionable (such as what it means to be a man).
$M$ any of these lessons are confirmed by the following case study in which Françoise Girard describes the Conscientizing Male Adolescents (CMA) program in Nigeria. Unlike many programs aimed at adolescent boys, which emphasize short-term activities aimed at preventing disease and unwanted pregnancy, CMA's model is a long-term program focusing on sexism and critical thinking skills. Boys meet for weekly

\section{As program designs become more sophisticated, we need to develop new outcome measures that can capture meaningful change in attitudes and behavior, even when those changes are multiply determined.}

discussions about such topics as gender-based oppression, sexual rights, violence, power within the family, intimate relationships, sexual health, human rights, and democracy. To help the boys develop as critical thinkers, the teachers rely heavily on Socratic dialogue and teach logic and verbal skills. Rather than target the out-of-school young people at highest risk, CMA recruits participants who are in school and who are particularly bright social leaders. The teachers' bold commitment to a sustained and intense engagement and to an unapologetic rights-based approach is a testament to a courageous and clear vision. Their success to date provides valuable lessons about helping young men in the transition to a healthy adulthood.

CMA has taken some initial steps toward evaluation. All programs seeking to alter the gender-power dynamics that underlie many behaviors associated with health face challenges with regard to assessing effectiveness. Changing indi- 
viduals' attitudes as well as social norms about gender roles is a long-term project and a difficult one to measure. In working with young people, the maturation process provides an additional confounding factor; because young people are constantly developing and changing, determining how much change was produced by an intervention and how much was due to natural maturation is difficult. As program designs become more sophisticated, we need to develop new outcome measures that can capture meaningful changes in attitudes and behavior, even when those changes are multiply determined. A few programs aimed at boys have begun this process. In Latin America, a coalition of four NGOs (in Brazil, Instituto PRO MUNDO, ECOS, and Programa PAPAI, and Salud y Género in M exico) have implemented Project $\mathrm{H}, \mathrm{a}$ theory- and research-driven model of engaging young men in the promotion of health and gender equity, with an evaluation model designed to measure attitudinal and behavioral change. ${ }^{1}$

From the examples of CMA, Project $\mathrm{H}$, and others, we can affirm that we do know how to engage young men, and that historically reinforced gender attitudes can change. The next step is to integrate such approaches into largescale programming, via schools, communities, the workplace, and the family. Taking gender roles and gender-based inequities seriously means that we take seriously how we rear boys. An extensive investment in gender-sensitive programs for boys is an investment in the next generation of husbands, fathers, and citizens.

\section{References}

Archer, John. 1984. "Gender roles as developmental pathways." British Journal of Social Psychology 23: 245-256.

- - - (ed.). 1994. Male Violence. London: Routledge.

Barker, Gary. 2000. "What about boys? A review and analysis of international literature on the health and developmental needs of adolescent boys." World Health O rganization. <http://www.who.org> Accessed $30 \mathrm{M}$ arch 2003.

- - - 2001. "Peace boys in a war zone: Identity and coping among adolescent men in a favela in Rio de Janeiro, Brazil." Erikson Institute, Loyola U niversity, Chicago. Doctoral dissertation.

Gilmore, David. 1990. Manhood in the Making: Cultural Concepts of Masculinity. New Haven: Yale U niversity Press.

M osher, D. and S. Tomkins. 1988. "Scripting the macho man: Hypermasculine socialization and enculturation." The Journal of Sex Research 25(1): 60-84.

Sonenstein, F., J. Pleck, and L. Ku. 1995. Why Young Men Don't U se Condoms: Factors Related to the Consistency of $U$ tilization. Washington, D C: U rban Institute.

United Nations. 1995. Report of the International Conference on Population and Development. UNDoc.A/CO NF.171/13. New York: U nited Nations. <http://www. unfpa.org> Accessed $30 \mathrm{M}$ arch 2003.

\footnotetext{
1 The Project $\mathrm{H}$ initiative emerged from context-specific research in Brazil that qualitatively assessed a continuum of more and less gender-equitable behavior and attitudes among young men (Barker 2001). Based on this research and the collective experiences of the four NGOs, the partner organizations developed a series of group educational activities (along with other community-based activities to promote changes in social norms) to engage young men in discussions about gender equity. Testing of the material in six countries in the region affirmed qualitative changes in attitudes about gender. Ongoing impact evaluation focuses on a series of questions concerning attitudes- some affirmations of traditional masculinity, some affirmations of more gender-equitable views-developed and tested with a random sample of young and adult men. Testing found not only that the scale was coherent and valid, but also highly correlated with a number of key behavioral variables (including self-reported condom use in last sexual encounter and self-reported use of violence against a female partner). The evaluation model (called the GEM Scale, Gender-Equitable Attitudes in Men) is currently being used in a large-scale impact evaluation study.
} 
In September 1994, Eddie Madunagu returned home to Calabar, Cross-River State, in the southeastern region of $\mathrm{Ni}$ geria. Madunagu, a nationally known and respected N igerian journalist, scholar, and political activist, was at a crossroads. The Guardian, the progressive newspaper where he was working in Lagos, had just been shut down by the Abacha military regime. The Nigerian socialist movement to which he belonged, like socialist movements everywhere after the fall of the Soviet Union, was in disarray. Madunagu's political beliefs precluded his returning to the University of Calabar to teach mathematics.

After years of struggle against oppressive military dictatorships, including a period of detention during his youth for his radical politics, Madunagu felt discouraged by Nigeria's lack of progress since the exhilarating days of the early post-Independence era. Despite the country's great oil wealth, the overwhelming majority of Nigerians were sliding into ever-greater poverty. Younger generations showed little interest in political engagement. Social injustice and oppression were evident everywhere, and community solidarity was breaking down.

Back in Calabar, Madunagu could not sit still for long. After some reflection, he decided that it was time for him to "get back to the basics" of his progressive activism - to educating, to developing the critical thinking and raising the consciousness of young people. As a first step, Madunagu planned to open a pub- lic library and documentation center with the many books he and his wife and fellow activist, Bene, had collected over the years.

The Madunagus' political awareness included gender issues (see Life Prospects for Girls and for Boys in Nigeria on page 6). Eddie's consciousness concerning women's rights had originally grown out of discussions with Ingrid Essien-O bot, a German feminist and Marxist who taught at the University of Calabar until her murder in 1981. His commitment to gender equity as a human rights issue, along with Bene's, only increased in subsequent years.

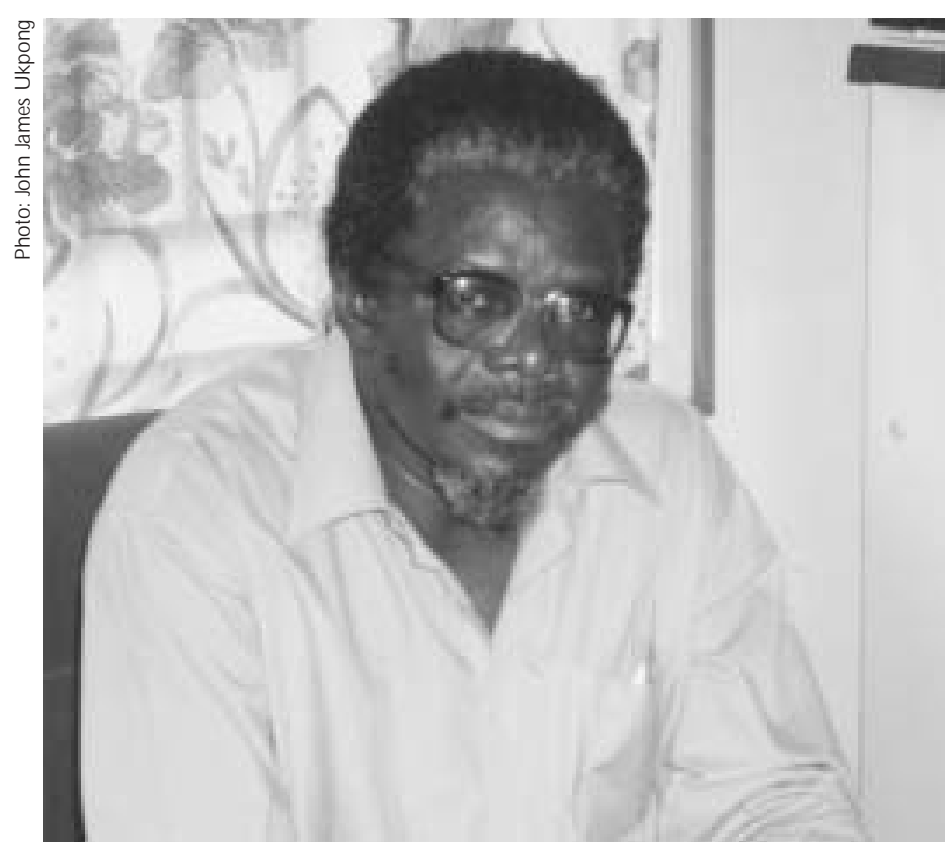

Eddie Madunagu is a warm, charismatic man, whose reputation for absolute integrity, unflagging energy, and prodigious intellectual output have earned him the respect and admiration of even his staunchest political opponents. 
Back in Calabar, Bene had just established Girls' Power Initiative (GPI), a new organization fostering the empowerment of adolescent girls. O ne evening, Andrea Irvin, the Program Officer for Africa of the International Women's Health Coalition (IWHC), joined Bene at the Madunagus' home to work on developing the GPI program.

Eddie Madunagu recalls that he walked in, and said, in a light-hearted manner: “D on't you know that boys also need this kind of program? Boys are not educated." Thinking back on that comment, Madunagu explains that he felt concern for the GPI girls, who, with all their newly acquired knowledge, would have to face "uneducated" boys and patriarchal families. "There is no point offering prayers and supplications to someone who is ignorant ... Women cannot achieve liberation by supplication." Madunagu was also thinking of the boys' own development and growth. He explains, "It is also necessary to let boys know that ultimately, men cannot win and cannot be truly happy and liberated as long as they hold down a section of society in bondage. . . . They have to understand that their superiority and advantages are, ultimately, illusory. ..."

Irvin suggested that Madunagu set up a program parallel to GPI for adolescent boys. For all his conviction, Madunagu readily admits that he resisted the idea for a while. Ultimately, as he says, "I had a desire to further develop my own gender consciousness." Thus was born a remarkable project: Conscientizing $M$ ale Adolescents (CMA).

\section{Life Prospects for Girls and for Boys in Nigeria}

Nigeria, the most populous country in Africa, has 120 million people, half of whom are 19 or younger. Fully 20 percent are aged 10-19, and another 30 percent are in the first decade of life. Their futures will be shaped by today's economic and social turmoil, cultural and parental pressures, and stark differences in the roles and prospects of adolescent girls and boys.

Women and girls are viewed as subordinate, and shoulder heavy work burdens in the home. Many families do not educate girls because they will marry and join their husband's family. The national median age at marriage is slightly younger than 17 for girls, who are generally married to much older men. Early marriage means an end to schooling and the first of many pregnancies, each carrying a high risk of complications and even death. Nigeria has one of the highest maternal mortality rates in the world.

Although many girls grow up in strict families that shelter them until they arrange their marriage, others face pervasive sexual harassment in school and elsewhere. In Lagos, for example, girls are often sent out to hawk goods on the streets, where men may persuade or force them to have sex. The negative consequences are obvious: unwanted pregnancies, unsafe abortions, sexually transmitted infections (STIs), and rising HIV infection rates among girls and young women. In one study, 40 percent of secondary-school girls interviewed said they had been pregnant at least once.

Nigerian boys learn early on that their society and culture consider men superior to women-in both the Muslim north and the Christian south. Men make most decisions, including decisions about childbearing and sexual relations. Cultural normscondone low rates of condom use, multiple sex partners for men, and sexual coercion of girls. Nigeria is one of the countries most at risk of explosive growth of HIV/AIDS. Adolescents, both males and females, rarely have access to basic information and education about their health or to health services. 


\section{The Origins of CMA}

In deciding to work with adolescent boys, Madunagu had two underlying assumptions. In the words of early CM A documents:

All the issues which are of concern to adolescent girls, including reproductive health and rights, sexual health and rights, fundamental human rights (including those rights specific to women), ignorance, poverty, powerlessness and alienation, exploitation and oppression, violence and indignity are, and should be, of concern to adolescent males and their elders.

Educating men on issues of specific concern and interest to women is an important, even critical, contribution to the universal struggle against the discrimination and injustices suffered by women and perpetrated mainly by men (or in the interest of men) both in private and in public life.

Irvin worked with Madunagu in developing a proposal for a program initially conceived as a complement to GPI. Madunagu decided to work with boys aged 14-20 because he believes boys in this age group are impressionable and typically "absorb the most backward social prejudices against women." He also believes that, because boys are "the beneficiaries" of a system characterized by inequality and oppression, they cannot be reached effectively until they are at least 14 or 15- an age when they can engage in intellectual debate and see parallels between patriarchy and other forms of oppressive power, such as the oppression of ethnic minorities and the exploitation of the poor.

The principal objective of the CMA program would be to engage adolescent males in ongoing discussion groups to increase their awareness of gender-based oppression. A second and equally important objective would be to foster participants' skills in critical thinking and analysis, teaching them, as Madunagu says, "to question information and reality before bowing before them." In this way, boys could arrive at a new set of values on their own, internalize them, and hone their ability to analyze what they discerned of the world around them. In addition to the discussion groups, CMA would provide counseling services and carry out community advocacy work.

Madunagu worked to establish a formal organization - the Calabar International Institute for Research, Information and Development (CIINSTRID) - that would provide an institutional home for CMA and house the library and documentation center (see information on CIINSTRID below).

In June 1995, Madunagu arranged to recruit from three secondary schools a pilot group of 25 adolescent boys interested in participating in two-hour dis-

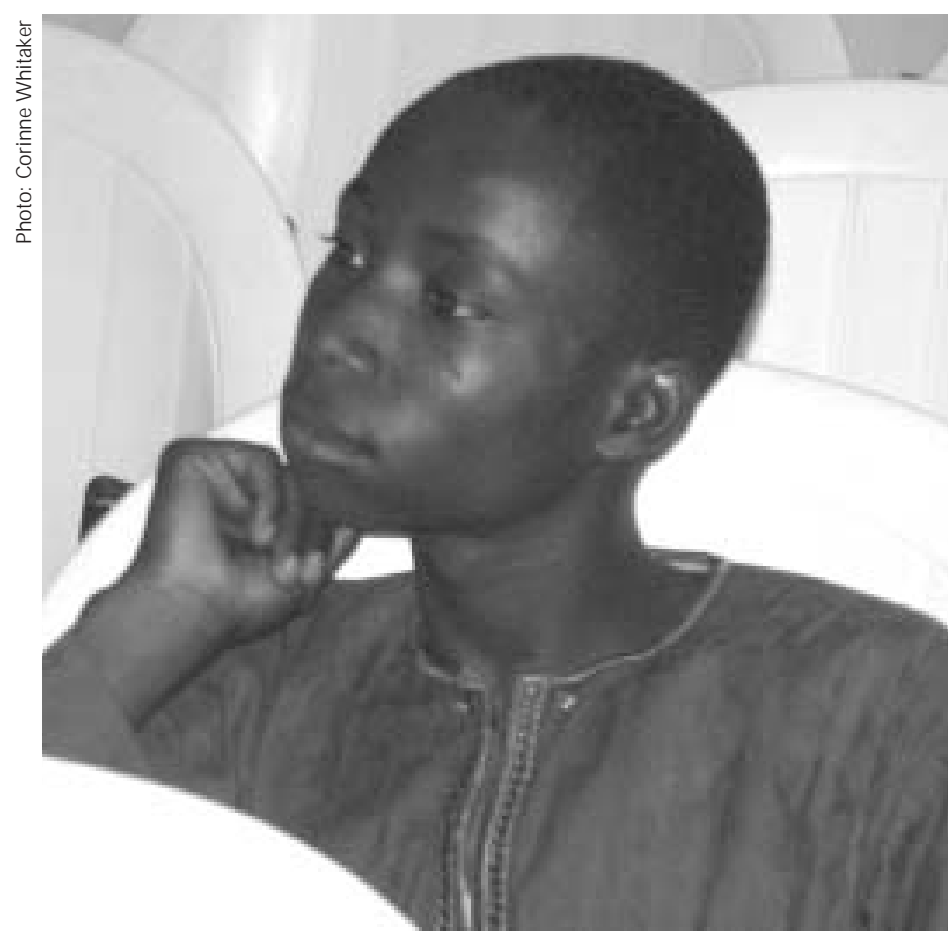

CMA was founded with two objectives: 1) to increase boys' awareness of gender-based oppression; and 2) to foster their critical thinking skills by teaching them to analyze the world around them and arrive at a new set of values on their own. 


\section{The Calabar International Institute for Research, Information and Development ( CIINSTR I D )}

CIINSTRID, the institutional home of the Conscientizing Male Adolescents (CMA) project, also houses a research library and documentation center. In operation since 1996, it is open to anyone in the community, seven days a week, free of charge. Located on the second floor of a modest building, its library houses an impressive collection of books, newspapers, and magazines on such subjects as Nigerian history and politics, Marxism, career planning, religion, feminism, and sexual and reproductive health. In recent years, the collection has been enriched through donations by several prominent Nigerian writers and academics, and by the International Women's Health Coalition (IWHC). Today, books and magazines overflow in an unruly manner into almost every room of CIINSTRID's offices. The library is well used by young and old of both sexes who come to consult materials unavailable anywhere else in Calabar or even in Nigeria. The library is a magnet for young people in particular.

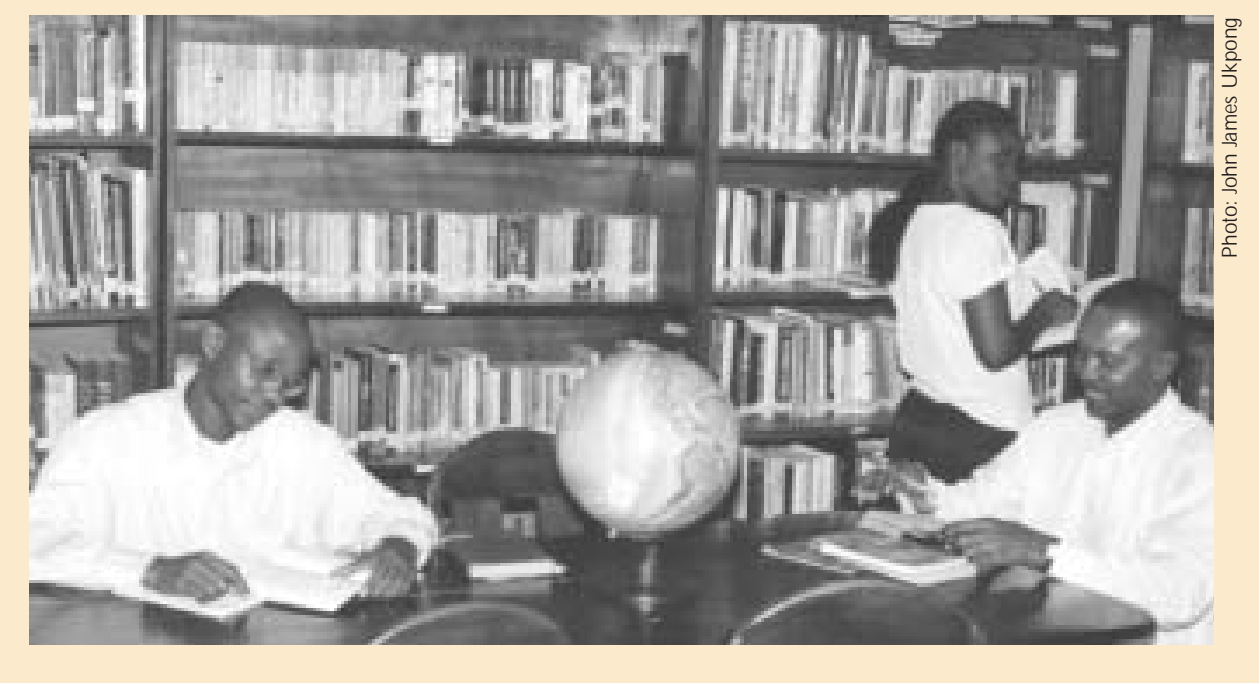

cussions sessions every week for an entire year. These boys tended to be strong students and social leaders, and $M$ adunagu used the discussions to identify the most relevant topics and to shape a sustained and intensive curriculum. After the pilot year, the program grew rapidly, and the early years involved constant restructuring. CMA began running the sessions at local schools, and then (with additional funding from the MacArthur Foundation) expanded to schools in Uyo, a town in the neighboring state of Akwa-Ibom. To handle the growing enrollment (250 boys in 1997), M adunagu began recruiting and training teachers to lead the groups. ${ }^{1}$

CMA's rapid growth and development created several dilemmas in its early years. First, the challenge of training secondary-school teachers to lead discussions soon became overwhelming. Second, many of the new teachers found moving through the intensive curriculum in one year difficult. Third, after

\footnotetext{
${ }^{1}$ As the organization has grown, Madunagu's role has shifted as well. In general, he now leads only CMA students' annual visit to CIIN STRID.
} 
completing the course, many boys wanted to continue meeting and learning.

In 1997, Madunagu decided to modify CM A's program, paring down the initial curriculum, but adding a second year for the most promising and committed boys. These consecutive programs were called Levels I and II. Level I still involves weekly two-hour meetings held at various schools. Level II groups have monthly one-day meetings at a Calabar hotel. They include 45 participants aged 17-19 drawn from various Level I groups.

\section{The Content}

Given Madunagu's own intellectual leanings, the initial CMA curriculum focused on Nigerian history and a broad social analysis of gender oppression. Early experience, however, showed that the boys were also concerned about subjects that touched them personally, such as inequality in the family, violence against girls and women, and relationships between boys and girls. Madunagu concluded that boys could be reached more effectively by integrating psychosocial approaches into the material, as Irvin had suggested in their early discussions.

Currently, the Level I curriculum explores fundamental concepts of gender and society, beginning with a unit on gender and sexism as social constructions. In this unit, students compare the biological differences between males and females to the difference in their social roles and power in Nigerian society. The students gradually realize that something beyond biology must account for gender inequality and that such inequality is unjust. The next lesson fosters understanding of how this injustice is perpetuated in the traditional family, considered a "private sphere" within Nigerian culture. Participants explore and debate the fact that women and girls-their mothers and sisters, for example-are often oppressed within the family and that adolescents and children of both sexes may also be subject to domestic abuse and violence. As participants' awareness and understanding increase, they examine violence against women as both a personal and a social phenomenon. Considerable attention is devoted to violence because it is pervasive in Nigerian society. Although the curriculum addresses such "traditional" sexual health topics as condoms, contraception, and STIS/HIV, these topics are given less emphasis.

Curriculum development is an ongoing process. A few years ago, when boys clearly were having trouble distin-

\section{Although Madunagu initially shaped the curriculum on broad social issues, he soon learned that the boys were also concerned about romance, family relationships, and violence at home.}

guishing love from sexual desire, a Level I curriculum unit was added on "men's responsibility in sexual relationships, love, and marriage," adapted from a GPI lesson.

The Level II course reviews the Level I topics but focuses more intensively on developing the boys' skills in effective communication, abstract thinking, and critical analysis. The curriculum includes such topics as logic and remedial English to support this skill-building. As another entry point to help students understand gender-based oppression, the discussion leaders draw analogies to other examples of oppression, such as poverty or ethnic violence. The Level II course also develops the boys' practical skills for intervening in their community and with their peers, for exam- 
Current Curriculum

\section{of CMA}

Level I

- Sexism, biology, and consciousness

- Discrimination against women and children in the family and in society

- Violence against women and the responsibilities of men, the state, and traditional authorities; rape; female genital mutilation; sexual harassment

- Sexual and reproductive health and rights

- Cultural impediments to gender equality

- Men's responsibilities in sexual relations, love, and marriage

- Human ecology and reproduction (social and physical conditions for healthy reproduction)

\section{Additionall Topics for}

\section{Level ||}

- Communications skills and the use of English

- Logic and method of mathematics

- Critical and antisexist introduction to Nigerian society

- Critical and antisexist introduction to world history

- Critical and antisexist introduction to democracy and human rights

- Feminism and the women's movement;

- Conscientization and society (critique of the present and vision of the future)

- Practical conscientization (social intervention and peer education)

- Adolescents and society

ple, during incidents of sexual harassment. The gender analysis still focuses primarily on women's experience, but Madunagu is developing materials on the negative impact on men of traditionally defined masculinity. $\mathrm{He}$ is searching for ways to address masculinity that are "not too abstract," for example, introducing discussions about how boys feel when they don't do well in sports, or when they are pressured by male peers to chase girls, or to be "macho" by displaying physical prowess and aggression.

CMA's paradigm is different from that of most programs aimed at adolescent boys. More conventional programs for boys emphasize sexual health, particularly condom education and distribution, and are often held in sports and youth centers. "Educational" contacts with youth may be limited to a few sessions. By contrast, the CM A curriculum is distinct:

1. The primary focus is on sexism and critical thought, not on preventing unwanted pregnancy, STIs, and HIV.

2. Power and oppression are discussed in depth.

3. The minimum contact time is one year, every week.

4. The program reaches not the most "at-risk," but some of the brightest and most motivated boys who are leaders in their schools.

5. "Extra" activities are primarily academic rather than social or athletic.

6 . The program is closely linked to and draws technical support from a sister project for girls.

Such a curriculum might not appear to be of enormous appeal to adolescent boys, and perhaps the bright and selfconfident young men that CM A engages are self-selecting to a degree. When I interviewed CMA boys about their reasons for joining the program, the reasons they named most often were that they enjoy associating with boys their age, that they were curious about the program's goals of fighting oppression and sexism, and that they wanted to learn to think critically, to make sense of their world. Contrary to expectations, none mentioned that his friends were joining, the opportunity to be tutored in school subjects (math and English), or Madunagu's reputation. In fact, most boys had never heard of Madunagu before they joined the program. 


\section{The Dialogue Approach}

The discussion groups at CMA use a modified dialogical method inspired by Paolo Freire's Pedagogy of the O ppressed (1970). This method involves a combination of dialogue, logical argument, and a supply of correct, often technical, information. The facts presented to the boys are facts they can verify themselvesexamples from life in their community and in Nigeria.

Each session begins with the discussion leader introducing a topic and giving some definitions. Rather than being taught through the traditional rote learning process, the boys are then led by means of questions and answers to perceive and analyze the contradictions in their own thinking. The aim is to nudge the participant to arrive at conclusions by himself. If that is not possible, the leader aims at a more limited objective, that is, to have a boy admit that a contradiction has arisen between his beliefs and the facts that he acknowledges are true. After leading students through the dialogue, the leader summarizes the discussion and proposes further deductions that might not have emerged in the discussion itself.

In recent years, as a result of staff training conducted by GPI, CMA has also embraced a number of other learning methods and techniques, such as role playing, brainstorming, "true or false" exercises, and "myths and realities." Combining these multiple techniques with the discussions has proved effective and engaging for secondary-school boys.

When I visited CIINSTRID and CMA in February 2002, at the end of its seventh project year, I had many questions. How could CMA convince teenage boys that they were oppressors, and that they had to change? Would boys really change, or merely pay lip service to gender equality?

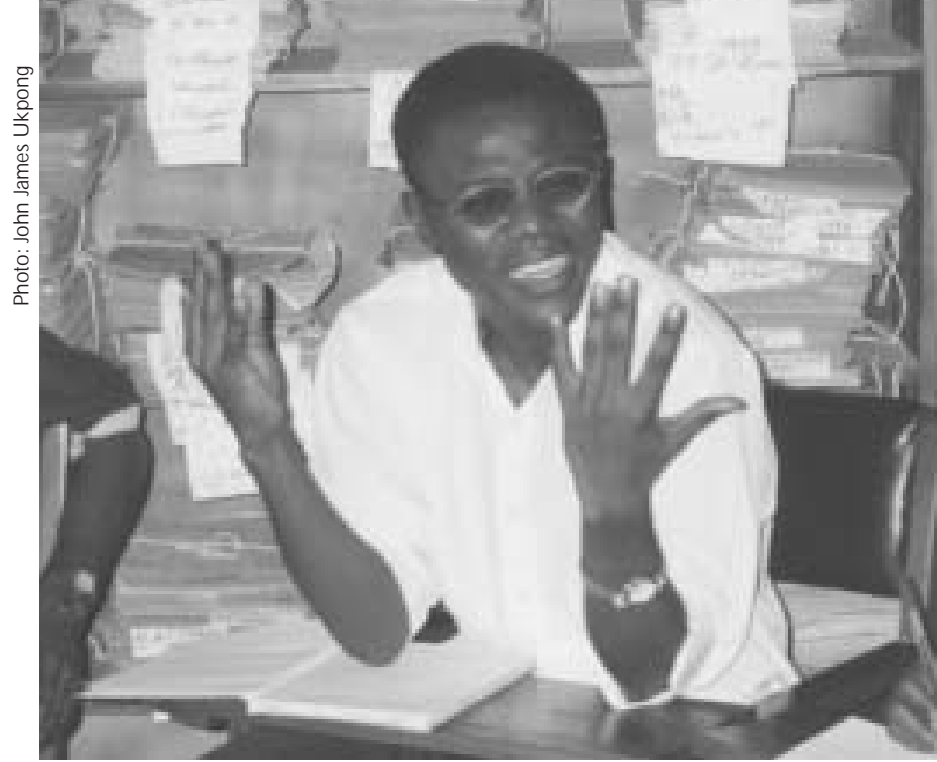

Field officers end discussions about rape by encouraging the boys to brainstorm about ways to address sexual violence.

I observed the graduation ceremony for CMA participants from Hope Waddell Training Institute and West African Peoples' Institute, two secondary schools in Calabar where CMA is active. The program consisted of a dialogic discussion on rape, and a skit on forced marriage and brideprice. The approach proved intriguing.

\section{Dialogical Method: Thinking about Rape}

Igwe Dermot, Vice-Principal of Hope Waddell and CMA Coordinating Field O fficer, led a brisk discussion. U sing a flipchart and markers, Dermot asked the boys what tender words they say to their girlfriends when they are with them in an intimate situation. Amid giggles, answers came from all directions:

"Honey, you are sweet!"

"Oh darling, I love you more than my mother."

"Oh baby, make me feel mad!"

"You are the only sugar in my tea. .."

The boys were then asked what their girlfriends say to them in those moments. The boys eagerly raised their hands:

"Darling, I will ever love you!

"You are killing me softly."

"Please hold me and don't let go."

"Take it softly, I'm dying." 
They were asked to compare those words with what girls say to them when they do not wish to have sex or spend time with them:

"Leave me please."

"I'm not feeling fine."

"I'm not in the mood."

"You must be mad."

"Love has nothing to do with sex."

Using the answers, Dermot then led them into a discussion of why boys think a girl means "yes" when she says "no." Energetic repartee ensued:

"Girls can't be seen to say yes, so they'll always say no."

"That's not true, a girl can say yes. I know that."

"If she comes to my house, doesn't it mean she's ready for anything?"

Dermot asks in return: "My neighbor comes to my house to talk to me, does it mean she's ready for anything?" Some boys reply, "No." O ne skeptic, Stanley, interjects: "But actions speak louder than words."

Dermot: "W hat are those actions?"

Stanley: "Wearing a mini-skirt. . . sitting close to me. .."

A 32-year-old female discussion leader: "But I'm sitting close to this other boy!" (The group laughs.)

Stanley: "W hat about the mini-skirt?"

Dermot: "You know the mad men and women on the main road, who walk around naked? Does doing that mean they're ready for sex?"

Stanley: "No!"

Dermot: "And when I'm sitting in my living room in my boxers, with my shirt open, does doing that mean I'm ready for sex?"

Group: "No!"

Stanley: "But I'm afraid you are saying we can't have sex."
CMA staff person: "No, you can have sex if you want to and if she wants to. But the question is, does she want to?"

Stanley sits back, mulling over the answers. Ultimately, the majority of boys, recognizing that they mean no when they say no, conclude that the same is true for girls.

The discussion then focused on defining rape. A debate ensued about whether it is better to rape than to masturbate. The group concluded that juxtaposing masturbation and rape in this way is inappropriate, and that rape is always unacceptable. Some boys said they needed more information about masturbation. The next topic was whether a woman can rape a man-a subject of evident fascination! The boys agreed ultimately that rape of men by women is not a significant social problem in Nigeria.

The boys then discussed why rape occurs by exploring the power relationships between men and women and the beliefs that men should be dominant and in control. The session ended with boys brainstorming about what they can do as activists to address rape. They decided they can inform other men and boys about what rape is; create awareness that rape is violence; counsel women and girls on rape prevention and how to deal with it; escort a girl or woman who is raped to the police or the hospital; intervene in cases of violence; speak up against harassment of girls; and change Nigerian laws to recognize marital rape as rape.

Throughout the discussion, it was obvious that not all the boys were at the same level of awareness. N onetheless, the climate of dialogue allowed for frank expression. A good number of the boys had obviously understood and integrated a critique of sexism into their own thinking, and were able to articulate arguments cogently and persuasively. A few of them resisted certain ideas, however, even at their graduation 
from the program and in front of an outside observer. Some asked for more information on certain topics. Some of the CM A staff themselves seemed still to be grappling with certain subjects. For example, one CMA staff member, a recent graduate of Level II, dismissed "the issue of lesbianism [as] not being that pronounced in Nigeria," and no one questioned his statement.

0 verall, the discussion was remarkably open. The boys were not shy about using accurate terminology, for example, penis, erection, sexual desire, and sexual relations. The language of moralizing and shame were absent. Dermot was a skilled leader, making the discussion lively and even fun. The atmosphere and tone were positive and respectful, and the majority of boys participated. The second discussion on the same subject that I observed a few days later at the Level I graduation ceremony in U yo was similar.

\section{Skit: Forced Marriage and Brideprice}

The skit on forced marriage and brideprice that followed the discussion was both hilarious and poignant. In full costumes and makeup, the boys acted out the story of a girl who cannot marry the village boy she loves because her father insists on receiving a high brideprice from the prospective groom. She is forced to marry an older man from Lagos who can afford to pay. Her marriage is bitterly unhappy, and her situation worsens when her husband dies. The village elders enter the scene, claim that she must have had something to do with her husband's death. They want to force her to drink the water that was used to bathe the corpse, "to prove that her hands are clean." In a subsequent discussion, boys expressed their feelings of injustice at the prospect of not being able to marry for love because one cannot afford to pay.

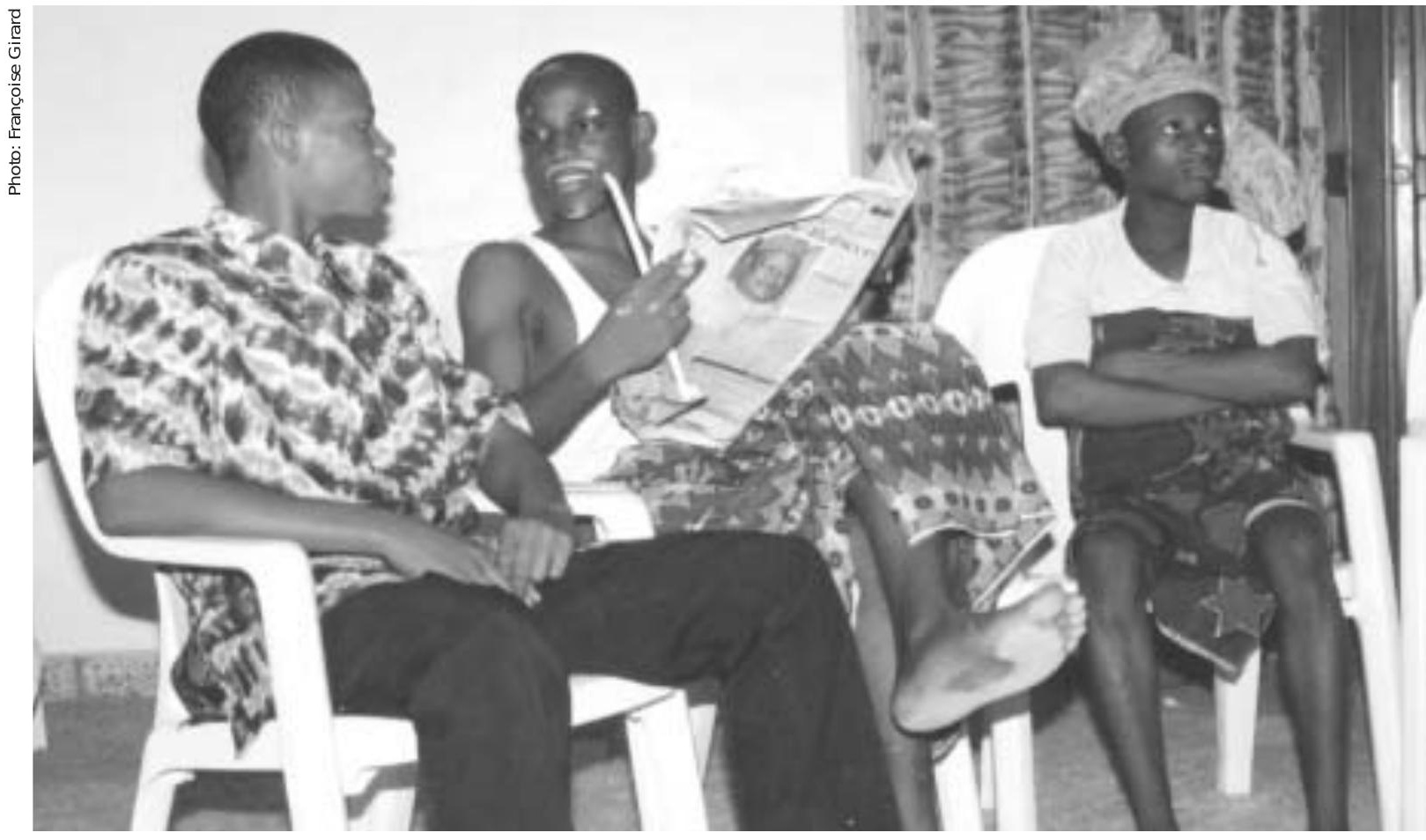

In a skit on marriage customs, the boys critiqued certain aspects of traditional Nigerian culture, such as brideprice, while also showing great fondness for many other aspects of their culture, such as its trove of proverbs. 


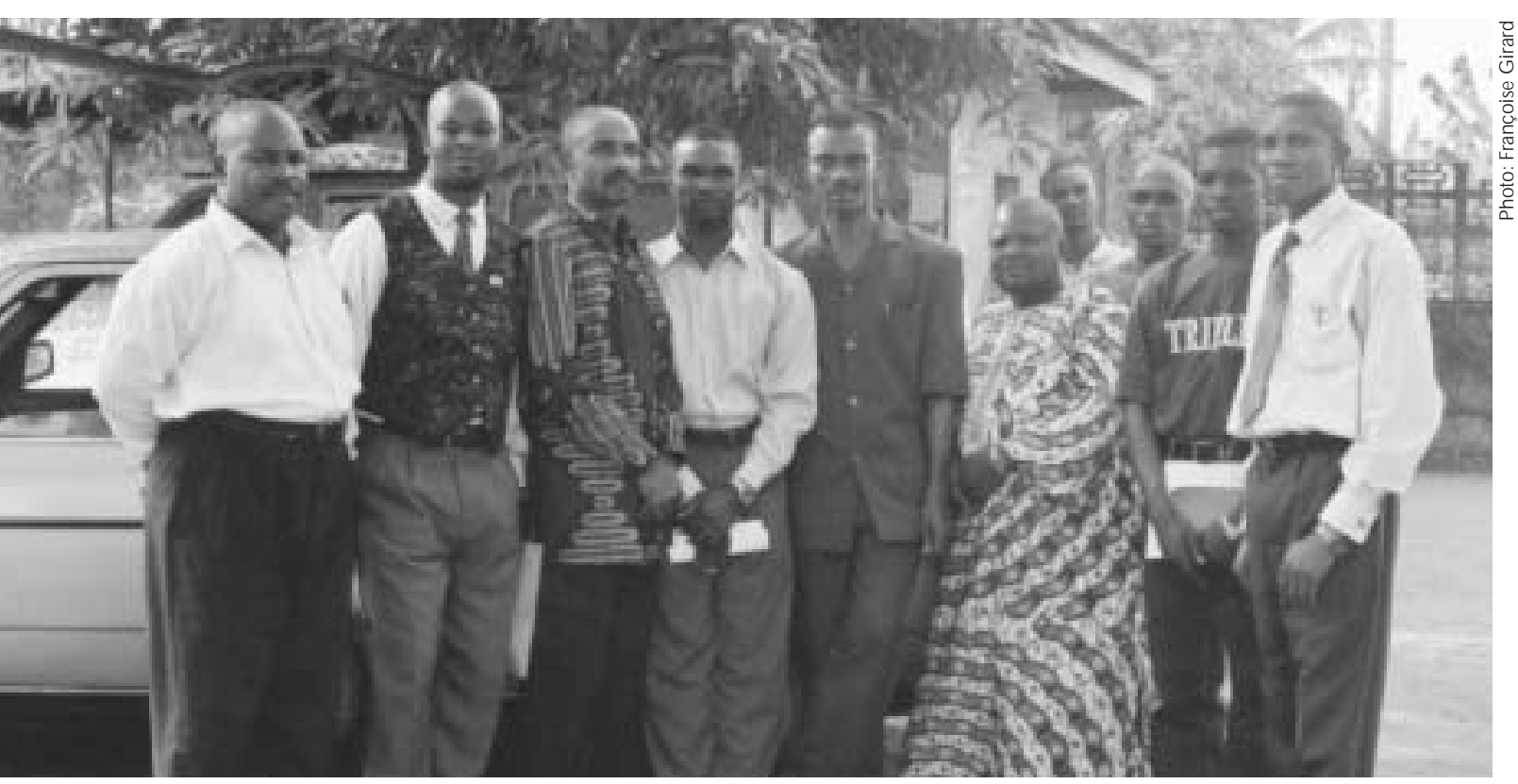

In identifying potential field officers, CMA looks for adult men who want to learn about sexism, are prepared to accept new ideas, and who can teach or lead. The challenge is a difficult one.

\section{Training Field \\ Officers and Staff}

To conduct the Level I discussions, CMA recruits and trains a corps of "field officers," who are teachers from participating schools. ${ }^{2}$ As Paul Awah, 21, a CMA graduate and associate discussion leader explains, identifying potential field officers is an ongoing challenge. Finding adult men who want to learn about sexism, are prepared to accept new ideas, and who can teach or lead is difficult.

Initially, Madunagu took a "leap in the dark," as he says, by asking school principals to select the teachers for training. The principals, however, often suggested inappropriate candidates: Some only wanted the stipend; others could not master the dialogical method or overcome their ingrained attitudes toward women. More recently, teacher selection appears to be going well; CM A staff members, current field officers,
CM A graduates, and current participants all provide input into teacher selection.

Field-officer training takes place at CMA and includes one intensive fiveday session, followed by four monthly one-day sessions. Because of the time and expense of traveling daily to Calabar from Uyo, CMA intends to house the $U$ yo teachers in Calabar during training and to change the format to two intensive five-day sessions (one in winter and one in summer), with review meetings in spring and fall.

For a while, Madunagu felt that CM A was not doing justice to some subjects in the training, and he decided to deepen CMA's relationship to GPI. GPI staff are, overall, more experienced and have received more expert training, in $\mathrm{N}$ igeria and abroad, than have CMA staff. Since 2000, GPI staff conduct the training sessions on Level I subjects, including men's responsibilities, feminism, and sexual and reproductive health and

\footnotetext{
${ }^{2} \mathrm{CMA}$ also provides basic training in most aspects of the curriculum to its entire staff, including administrative staff who do not lead discussion groups.
} 
rights. CMA trainers continue to cover such Level II topics as communication skills, English, and Nigerian history.

The Level II discussions are led by CMA staff, some of whom are adolescents who have graduated from a previous Level II course. Training to conduct Level II groups is carried out by more experienced CM A staff and by GPI staff, and places particular emphasis on verbal skills and "conscientization techniques," the art of leading dialogical debates, and other group exercises.

In 2000, in order to help guide the field officers and staff for group discussions, CMA developed a manual based on notes that they had compiled over several years. The manual specifies the objectives and a brief outline for each session, suggests questions and activities, and includes a short list of reference material for further reading. This information is a good starting point, but most field officers need additional guidance, such as a step-by-step description of exercises. As a result, CM A has produced more detailed discussion notes on each topic. The manual will soon be expanded and revised, with assistance from GPI staff.

\section{Beyond Level\|}

A few years ago, a small group of Level II graduates formed a "CMA Vanguard," to speak out and organize discussions and activities in their communities. Although these young men are particularly bright and committed, they are still adolescents and have found it difficult to act systematically without continued support from CMA. As a result, they are making a transition into a "Level III" group that will meet regularly with CMA staff. Graduates of Levels II and III are in many ways a cadre for a new generation of young leaders in their communities.

As CMA staff gained experience in working with older adolescents, they also began working with a group of 18-25-year-old students at the U niversity of Calabar. Because many of the participants are entirely new to CMA (that is, they have not gone through Levels I-III), this component is called "Special Group." Since 1999, the 25 Special Group students, facilitated by CM A staff, meet once a week for two hours. They focus on violence against women and sexual harassment, which are particularly serious problems at the university.

\section{The Counseling Service}

Soon after the program was established, Madunagu and his staff became aware that some boys needed in-depth counseling. Some had personal problems, whereas others wanted to discuss their personal goals and aspirations or to ask more questions about issues generated in group meetings. A service was established in 1996, but initially it was more

\section{CMA continues to rely on the Girls' Power Initiative for aspects of its teacher training as well as for staffing the counseling service.}

akin to education than to intensive, one-on-one counseling. In 1999, CM A revised the approach and hired a professional to help the boys' with problem solving and decisionmaking. Unfortunately, the first counselor proved to be unsatisfactory, and use of the service remained low. In 2001, CMA contracted for services from GPI counselors, who now spend up to five hours a week at CMA. In the first months of this improved service, use jumped to an average of seven students per week. Never- 
theless, the service remains underused, in part because of cultural impediments ("It's a foreign idea"), and in part because the field officers have not publicized the service or referred their students. CMA is now actively encouraging field officers to make referrals.

All CMA participants are expected to come for general counseling once a year, and most do. This session gives boys and CMA staff a chance to discuss any issue of concern with a counselor, be it a family matter or a question about school or career. Moreover, boys can come in for special counseling as needed. The boys with whom I spoke and who had chosen to see the counselor said that they were satisfied with the advice and information they had received, except for one Special Group student who thought that the level of counseling he received was more appropriate for younger boys. O ne boy mentioned that he appreciated the confidentiality of the counseling at CMA, something that was not characteristic of other such services offered to young people in Calabar.

\section{Counseling Case Studies"}

\section{Adeyeni, 16, Level II}

Adeyeni witnessed a man beating a woman and tearing her clothes. Adeyeni did not know these two people, but he feels that he should have done something to stop the beating. He wants to know what he could have done. Based on their discussion, the counselor concurs with Adeyeni that, given the particular facts of this situation, he probably could have done nothing directly except call the police.

\section{Stanley, 19, Level I}

Stanley is madly in love with a girl who had broken up with her first boyfriend when she met Stanley. She soon made up with her first boyfriend and left Stanley. Stanley reports that at this point he cannot eat, concentrate, or even play volleyball. The counselor and Stanley discuss the short relationship he had with this girl. Stanley comes to the conclusion that he alone was in love, and that the girl used him as an emotional bridge during her separation with the first boyfriend. Stanley says he will go out more and see friends to try to forget the girl. He says he feels sad, but relieved of tension.

\section{Duke, 17, Level II}

Duke is reserved and finds it difficult to interact with people. He would like to share the knowledge he acquired in CMA, but cannot bring himself to do it. The counselor discovers that Duke is not as shy with his brothers and sisters, so she suggests that he practice talking about CMA with them as a first step. She also suggests he asks a brother to accompany him when he talks to others about CMA.

\section{Benjamin, 18, Level II}

Benjamin wants to remain totally abstinent until marriage because of his religious beliefs, but is not sure he can manage it. The counselor probes to find out what Benjamin means by total abstinence. They discuss various ways of expressing love and sexual feelings without full intercourse. Although Benjamin says he cannot consider masturbation because of his religion, he feels that he can consider other methods for "outercourse."

* All names have been changed to protect students' privacy. 


\section{Community Work}

Many CMA graduates are trained to intervene in their communities and with their peers when they witness incidents that violate the rights of women. Community skills are initially developed in the Level II course, which tends to attract the best and the brightest participants. Community skills are also an essential part of the Special Group program. CMA Vanguard/Level III participants are expected both to organize such activities as public debates and to intervene in particular incidents, for example, challenging a derogatory remark about women and working to help others understand why it is wrong. Participants have told CMA when a family in the neighborhood is planning to have their daughter undergo genital cutting. Madunagu reports that CMA has persuaded a few families not to go through with this procedure.

CM A and the boys are learning, however, that interventions can become complicated, and that some violent situations can be dangerous or hurtful to the boys themselves. In one case, a Level II student reported that a neighborhood girl was going to be subjected to genital cutting. CMA staff sent a letter to her family and talked to her parents. This contact apparently prevented the cutting, but the boy's father threw him out of the house for a week for "causing problems," and the girl's family harassed the boy for several weeks, calling him an "informant." The boy turned to the CMA counselor for help, and the situation calmed down.

Every year in O ctober, CMA organizes a Saturday forum for the parents and guardians of CMA boys to give them more information about CMA, and to find out from them how CMA has changed their sons. Parents suggested that CMA begin a radio program, and organize open-air forums for the public. ${ }^{3}$ O verall attendance at the parents' forum has been disappointing, however, perhaps because field officers do not publicize it sufficiently and because parents are busy.

Every year, Level II and Special Group participants are invited to visit institutions and enterprises to learn more about

\section{CMA's quarterly newsletter has provided an impetus for father-son discussions.}

the economic life and history of the region. Last year, for example, students visited the Cross River Broadcasting Corporation, the National Museum, the Nigerian Port Authority, and the Calabar Free Trade Zone. Attendance at these excursions is lower than expected for reasons that remain unclear.

Finally, the program publishes a quarterly newsletter, The Male Adolescent (TMA), with funding from the MacArthur Foundation and IWHC. The aim is to spread the message of CMA to the general public. TMA is produced by CMA staff with contributions from students. Content includes accounts and photos of CMA events; articles on topical subjects (for example, domestic violence, democracy in N igeria, sexual health and rights, what to do in case of rape); features on skills (including counseling, facilitating, and training); book reviews; and an editorial by M adunagu (for example, "Politics in the Age of Hate"). Although the content is interesting, the presentation is dense and academic, and the layout and production quality is rather weak. N evertheless, TMA reaches many people outside the program, notably parents. Several CMA boys told me that their fathers read it and that it has provided the impetus for father-son discussions.

\footnotetext{
${ }^{3}$ CMA now plans to hold three such public forums a year-on women's rights as human rights, on antisexism and male responsibility, and on democracy and human rights.
} 


\section{In Their Own Words: CMA Boys Reflect}

The CM A graduates I interviewed ranged in age from 16 to 25 . Two had completed only Level I, four had gone through Level II, three have joined Vanguard/ Level III, and one was in Special Group. $N$ ot surprisingly, the understanding and articulation of the ideas of CMA was much better among the more advanced students than among the younger, Level I boys. In the excerpts below, the CMA boys discuss the influence of the program on their identities and their world views. ${ }^{4}$

\section{On Gender Equality}

Most boys were eager to express their views about discrimination against women in politics, education, and the home, and about why women should be considered and treated equally.

Women are politically marginalized. Only one woman is a deputy governor of a state, and there is a problem with the governor, a man, because he is a sexist. ... The fact that Nigeria is patriarchal is not helping the development of the country. Parents tell a girl to get married; they think she is not worth educating. They spend a lot of money educating a boy, but not every boy becomes something. Women are not supposed to be heard. If a woman talks, she is told to sit down. ...

\section{Moses, 16, Levels I and II graduate}

Most people think it is impossible that a woman can be president of $\mathrm{N}$ igeria. I think, why not in 2003? It's possible, because the differences between men and women are only the reproductive organs. Women can do what men can do.

Abu, 17, Level II graduate

Before, I did not know that women have a right to express their opinion in the family. Now I know it. I thought that only women should wake up early in the morning to work, and that men can sleep. N ow, I wake up early before my sister, sweep the floor and help out. Sweeping the floor is not just the work of a woman. . . My mother tried to stop it, but I explained to her. Now she is proud of it.

Felix, 18, Level II graduate

When it comes to ruling and politics, give women a chance to contribute. Maybe they have better ideas than men do.

\section{Kingsley, 18, Level I graduate}

\section{On Sexual Harassment and Violence against Women}

The boys understand that their past behavior of harassing and touching girls was a violation of girls' rights. A few of the boys spoke of "protecting girls," a somewhat patriarchal approach to the subject.

My friends who are not in CMA ... they see a girl passing, they'll whisper embarrassing things, touching the girl, saying some things that are not pleasant to the girl. Already some of us that have been in CMA have been told not to do so, because it will make girls embarrassed. ... I've stopped all this whispering, standing on the road, touching girls anyhow ... I I abstain from those things now. . . .

\section{Kingsley, 18, Level I graduate}

This is what I feel the world should look like. D on't you want a world of peace, don't you want a world where there is equity? Do you want a world where our fathers will be beating up our mothers? A world where our brothers will be beating up their girlfriends or our sisters will be beaten up by their boyfriends?

... Culture is dynamic, it is not static. We are not overruling culture. There are aspects of our culture that are bad. That is what we kick against.

Paul, 21, CM A levels I and II graduate, now CMA staff member

\footnotetext{
${ }^{4}$ All boys' and parents' names have been changed.
} 
A few boys still had mixed feelings about women, violence, and sex. They saw women or girls as "temptresses," yet also expressed some understanding:

I saw one man struggling with a girl at the university. I went to talk to him, and four other boys came, so the guy ran away. I told the girl to change her mode of dress. It was at night. It's dark, if you wear this kind of dress, other men will harass you! In the day you can wear what you want. . . . There are women who go there [in bushes] to give sex for money, at a place nearby. If women stopped going there, that would stop many problems. But there are no jobs in this country! Even for

\section{In reflecting on love and}

marriage, a number of boys

articulated a desire for a very

different relationship from that

of their fathers with their

mothers. They expressed

particular concerns about early

marriage and polygamy.

those people who have an education. That is why they do this, maybe. It's not fair. It's not good.

Emeka, 21, Level I graduate

\section{On Early Sexual Relationships and Sexual Health}

All boys talked to me about unwanted pregnancy and the need to refrain from sex if they were not ready for it. A common theme was that it is possible to have friendships with girls without necessarily being sexual, apparently not a widely held belief among young men in Nigeria.
We discuss these issues in CMA, about girlfriends and boyfriends. Many have sex, but since they don't know anything, the girls get pregnant. Boys need to think. . . . They can be friends with a girl without sex. Don't have sex if you're not ready.

Emeka, 21, Level I graduate

Most boys had some knowledge of sexual and reproductive health, although not uniformly. Some Level I teachers apparently are uncomfortable with this topic. O ne of the Level I boys said he had learned nothing in CMA about sexual and reproductive health, condoms, HIV, or anything else of that nature. Level II boys said they discussed the need for family planning and knew about oral contraceptives, IUDs, and condoms, as well as sexually transmitted infections, including HIV.

\section{On Education and Prospects for the Future}

I am worried about how to graduate from the university with a first degree. There are so many strikes in the university. The lecturers don't send in the results of exams. I have to chase them for the results. That is what I have been doing for the last few days. I wonder what life will be like? Will I get a reasonable job? If I do, will I want to settle and marry? How do I go about it? Will the community let me be myself, make my own decisions?

\section{Victor, 25, Special Group}

\section{On Marriage and Fathering}

Most of the respondents had reflected a great deal on love and marriage. Several said they wanted a very different relationship from that of their fathers with their mothers. They expressed particular concerns about early marriage and polygamy:

For example, now if one day I marry a woman and decide to divorce that woman, and this woman had a child 


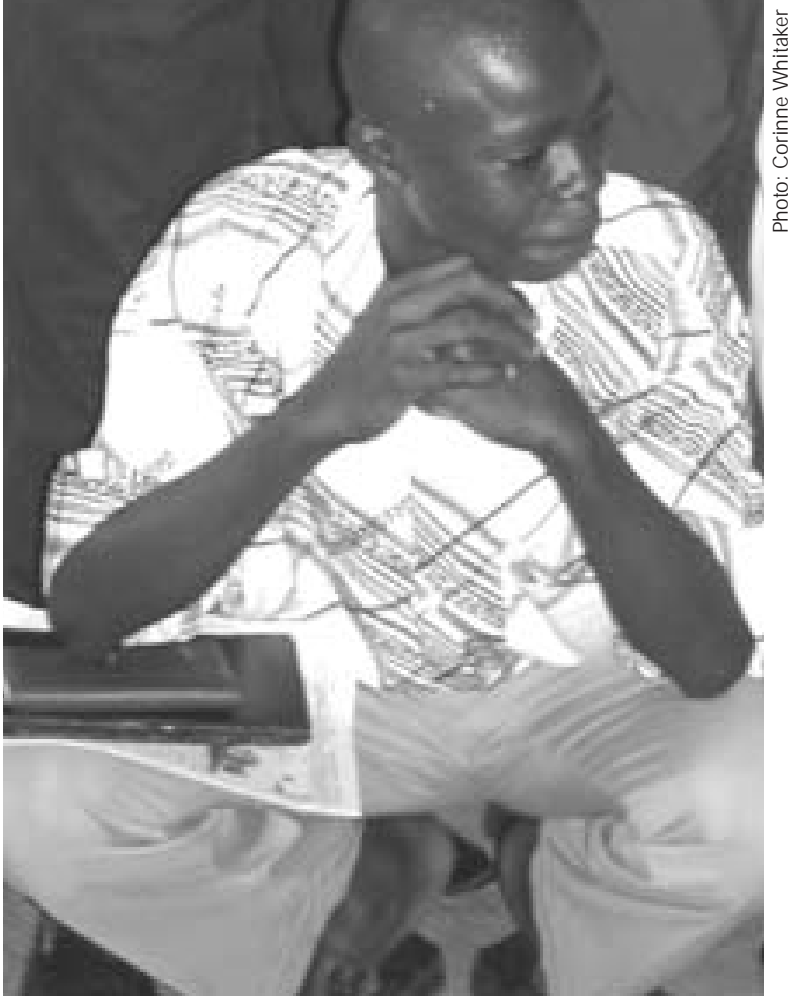

from me. What'll I do? I'Il make sure that I'll take care of that baby and provide a comfortable life for the mother also. ... I'Il make sure that I'll end the relationship in a way that even the woman would not be hurt.

My father did not think this way. He would send the woman and the baby away and would not want to know anything about it. That's basically what he did with his first wife and children [Harry's stepbrothers and stepsisters]. . . . The reason I'll be different is because of CM A.

Harry, 20, Levels I and II graduate, now member of CM A Vanguard

I would not have more than one wife, because of the problem my dad is facing now. He is regretting he married more than one wife. Children of different marriages are not treated equally.

Felix, 18, Level II graduate

I'll be a different husband [from the way my father is]. I won't just pick any woman! There must be courtship. We must reach certain agreements, must understand each other and agree on how our lives will be. I must understand my wife, know her feelings, and we must agree on almost everything. I'll be by my wife. I'll share domestic chores, support her outside the home, give her her freedom, I won't tie her down, I'll allow her to explore her own world. I'm not everything that matters.

Victor, 25, Special Group member

\section{What About Behavior? Girls and Adults Talk about the CMA Boys}

With the exception of one school in Calabar, all participating schools are coeducational, thus providing an immediate environment that tests the boys' changed attitudes. I spoke to a few GPI girls and adult women from GPI and CM A, and with a community leader from South Calabar. They had seen noticeable changes in the CMA boys' behavior and attitudes toward girls and women.

I know several CMA boys, including one of my neighbors. Before, they used to have many girlfriends, say that you can use the weaker sex ... . make bad comments when a girl passed by. N ow they stick to one girlfriend and don't bring her down. They don't harass girls anymore. O ne of them in university is a feminist. $\mathrm{He}$ does work on the rights of women globally, all aspects, political, economic, decisionmaking ....

Grace, 18, GPI girl, university student

I know a boy from CMA in school. He is not behaving as the other boys do. He can speak in public, he can tell boys how to avoid sexually transmitted diseases, HIV and AIDS. . . . I've seen him do that. Before CMA, he behaved as someone ignorant. ... He could not talk in public, was very shy, but he harassed girls.

Veronica, 16, GPI girl, secondary-school student 
Adults-parents, community leaders, and CMA staff-concur with Grace and Veronica (see page 21). A number of parents were initially skeptical about their sons' joining $\mathrm{CMA}$, in part because some young people are joining groups perceived as cults. O nly after listening to their sons and seeing changes in their behavior have these parents changed their views. Several parents whose sons are now in their third year with the program remarked on the change:

You know that we are living in an area that is dominated by "area boys," and of course, the issue of cults in schools is very rampant now, so I thought he was doing some cover-up. . . . [Then] the first thing I observed was when he started cooking at home because ... boys are not supposed to do such things, and I asked him where he learned that from, and he said from the CMA program. Then I asked what was meant by CMA, and he told me. Secondly, I observed that he was becoming more responsible, that is, he no longer waits for somebody to urge him to do something before he does it, so again I asked him why the sudden change in his behavior, and he said it was through CMA. Then I said thank God, but I was still skeptical about this program. I have since realized that the CMA program is designed to correct the ills going on in the society.

\section{Mr. Uwem Esu}

Before, hardly a week passed without neighbors coming to complain of [my son's] bad behavior, like his fighting with the neighbor's child. Even in school, I was getting a lot of bad reports about him. My son told me CMA was an educational program on women's rights, so I just told him that he should be careful so as not to join a secret society, since he was a very stubborn boy. But now he is a completely changed person, because he is always at home and takes his studies more seriously than ever. He now educates others on the need for them to stop violence against women.
You know, in this house, we have a roster for domestic chores. Before, whenever it was [my son's] turn to do things in the house, he always proved very stubborn. But now, he doesn't only freely take part in domestic chores, but he is the one preparing the roster and seeing to the compliance by others. I'm not always at home because I'm a trader, but I have also observed that whenever he comes back from the CMA program, he will share the information with others in the house, especially the sister.

\section{Mrs. Comfort A toe}

Here was a boy who was very timid. I have observed with keen interest that he is very outspoken now. He has been able to instill, especially in the sisters, some element of selfesteem, using those newsletters, but more so through he way he talks.

The first time I came across the CMA information bulletin, I was alarmed because of the issue of "critical consciousness." I thought that [those] people are out to create rascals and children who will come back home and start fighting their parents all in the name of education. So I had to warn my son to know the type of company he keeps or else he will soon land himself in prison. N ow I think [CMA is] doing a very good work in the lives of these adolescents by molding them into responsible adults. I'm saying this because of the transformation in the life of my son and his being able to use such information to influence the lives of his sisters. I can now say that CM A is out to transform and not to destroy. 
Community leaders see the CMA boys outside of their homes, and describe them:

There are about 12 CMA boys in my community, and they are active, very active. These boys read a lot. They never used to read, but now they read a lot. They reach out to hundreds of boys. Before, when the girls went to fetch water, boys would wait for them to touch their breasts and their bums, to make them feel bad. . . . CM A boys organized a meeting on the theme of "the love for a girl child." They invited a cross-section of boys, men, girls, in the end we had about 500 people in the community hall. The discussion was about thinking of girls as human beings . . . think of your sister, your mother. . . . It brought boys and girls closer.

Sandra, community leader

I see a very big difference. . . . If young boys are conscientized, educated, it makes the ground softer for [GPI's] work and for society in general ... . because when they interact with members of the opposite sex, they now incorporate women in decisionmaking. ... It makes relationships flow. . . . GPI girls interact with CMA boys. CMA boys understand that they can be friends, it's not only about sex! Girls can discuss, express themselves with CMA boys.

\section{Helen, GPI facilitator}

School principals come here to ask for the program and to ask that more of their students participate in the program. The new principal of West African Peoples' Institution saw the CM A boys, the way they intervene in matters regarding girls, and she was impressed. She told me she wants more than 30 students in there.

Winifred, CM A staff member

CMA has the impact it does because it targets boys at the age where they can most easily change.

Igwe Dermot, CM A co-ordinating field officer
It appears that the influence of the CMA boys on their peers is gradually changing prevailing norms of social behavior at school. One teacher in Calabar reported that a small group of bullies at his school had harassed girls and other boys constantly. $O$ ne of them, a natural leader, joined CMA, and has since stopped harassing others. $\mathrm{H}$ is fellow bullies, who are not in CMA, do not seem to understand his new ideas, but they can see that he and a few others are changing their behavior and tak-

\section{Asked how working with only 30 boys a year could make such a dif- ference in a large school, one teacher replied that the CMA boys are the brightest, and that many of them are leaders. They set the tone.}

ing their studies more seriously. Peer pressure has gradually encouraged them to stop harassing others, even if they do not necessarily understand why.

Teachers at the Christian Commercial Secondary School, a coeducational secondary school in Uyo, reported a dramatic transformation in the behavior of boys and in the relationship between male and female students as a result of CMA. According to one teacher, before the CMA program, boys harassed girls so much that girls would refuse to sit in the school library. Now, he sees boys and girls sitting together quietly, and shakes his head in amazement. When asked how working with only 30 boys a year could make such a difference in a large school, he replied that the CMA boys are the brightest, and that many of them are leaders. They set the tone.

Another teacher mentioned that a nearby girls' school gets out at about the same time, and that, in the past, many incidents of harassment occurred. 
Today, the harassment is dramatically reduced. Teachers also describe how the girls in their school heard about CMA, and asked that GPI groups be set up for them. GPI now works in several schools in Uyo.

The impact of CMA teachers as role models in the school was also mentioned in my interviews. Harassment of female students by male teachers is common in Nigerian schools. Boys (and girls) are intrigued by these teachers who practice what they preach. Many boys seek them out as mentors and advisors.

\section{Teachers as Learners}

CMA field officers, who lead the discussion groups, report that they have learned a lot from the program and are enthusiastic about teaching this material. Some said that it had changed their own behavior dramatically:

I was wonderfully transformed, yes. ... I was one of those who feel a woman does not have the right to eat my money without paying back. Not that I would rape you, ... but I would give you this kind of heat ... pressure ... then gradually, you realize that, after everything, there is no joy on the part of the woman, that you have wronged somebody ...

Charles, teacher, former CM A co-ordinating field officer/ discussion leader

The program is really going places. I'm very excited by what we do.... It is an advantage for me to be a woman and lead discussions. I tell them stories about my family and my life. They love those stories! The boys ask me questions. They relate very freely with me. If I had had this kind of information at 15 [she was married at 15 , and has five children], my life would have been different.

Mercy, CM A staff member, discussion leader for Level II and Special Group

I used to think that whatever relationship you are having with a girl, it just has to do with sexual relationships, that a boy cannot relate to a girl without the sexual aspect of it. ... I have changed a great deal!

Alphonsus, 27, CM A staff member (joined staff at 21 in 1996)

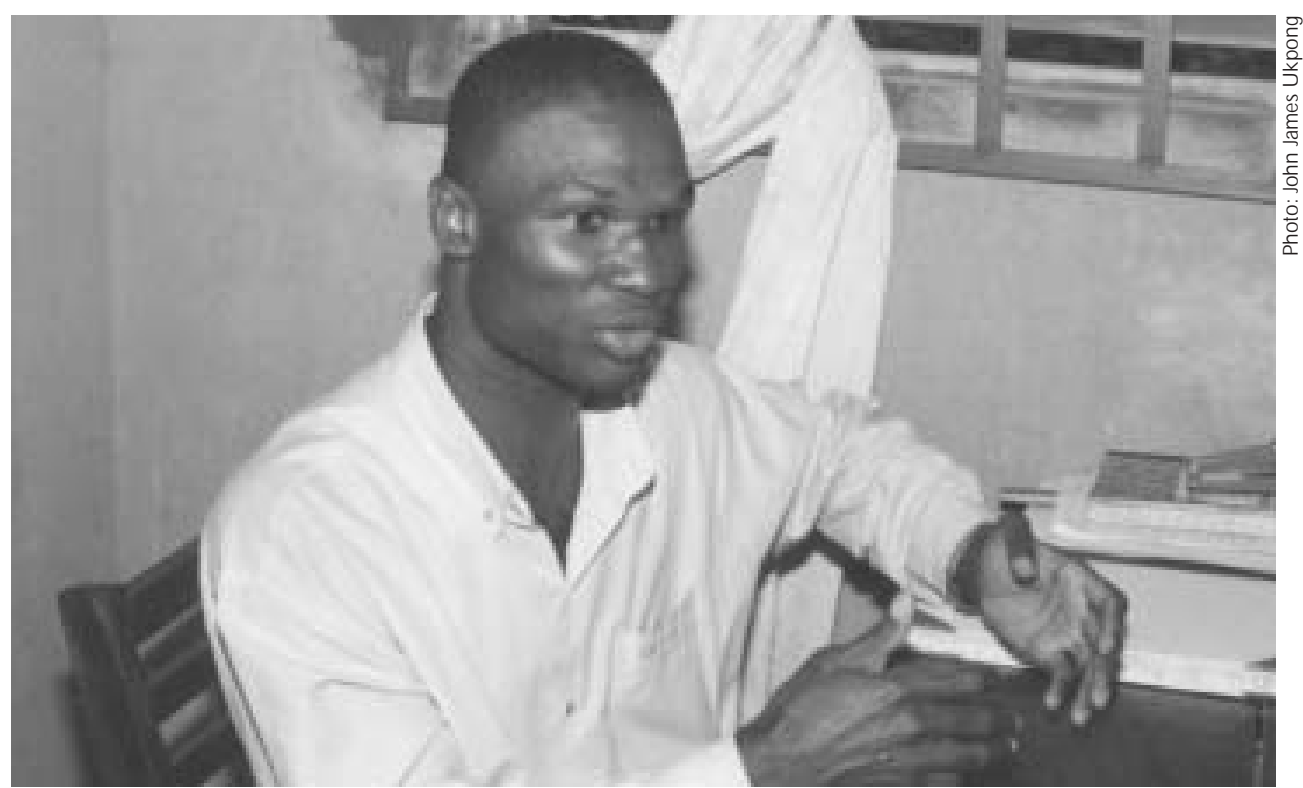

Field officers such as Alphonsus Ekah report that working at CMA has deeply affected their own beliefs and behavior. 


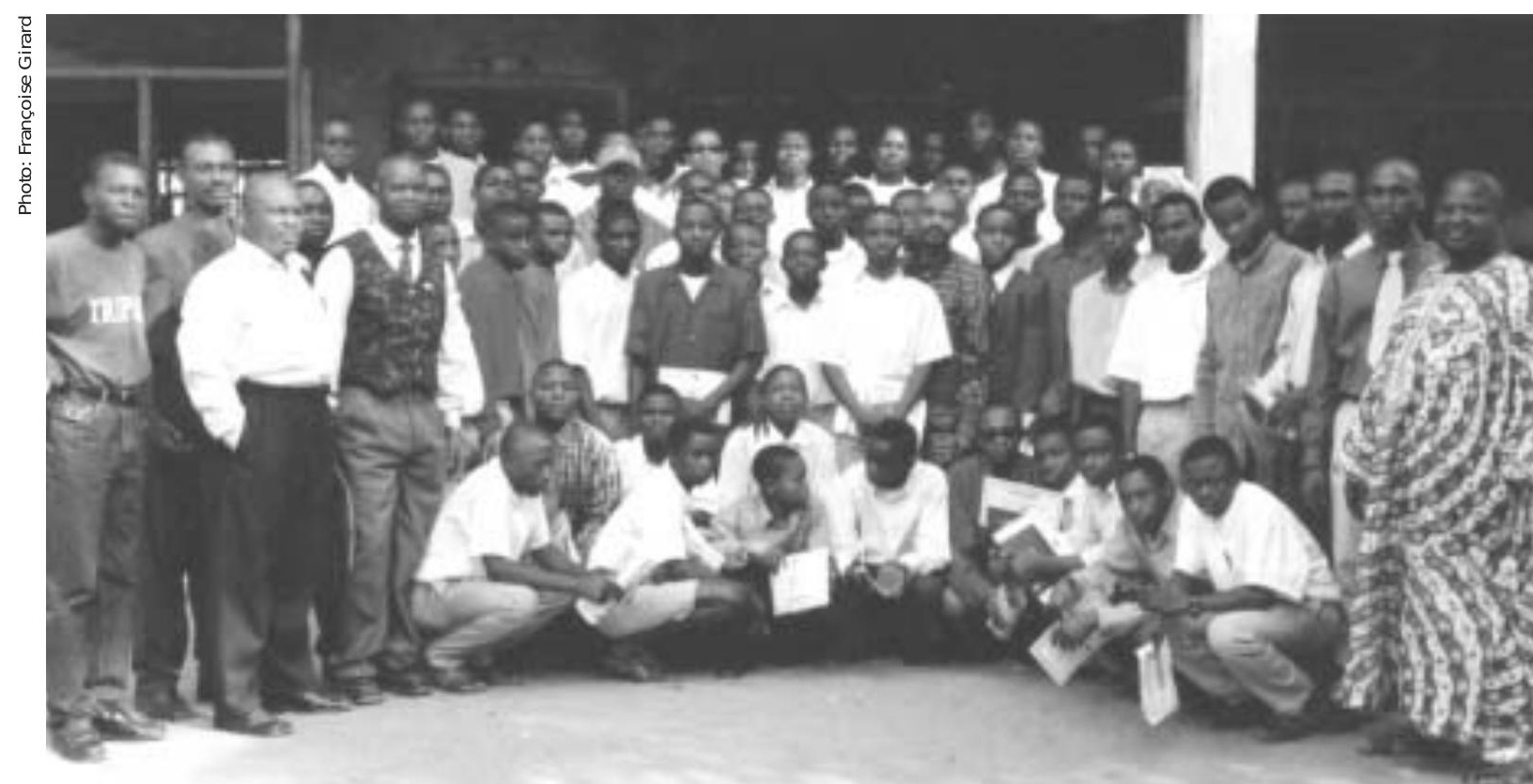

Because the 2,000 CMA graduates are, by and large, unusually competent and influential, the program's influence is vastly multiplied.

\section{CMA as a Social Change Agent}

When Madunagu founded CMA, his objective was to create a male complement to the Girls' Power Initiative. O ver time, his vision for the organization has evolved. He now views CMA's workfostering antisexist and critical consciousness-to be an important aspect of the struggle for the broader democratization of Nigeria, for three reasons: First, CM A reaches a large and growing number of boys and has a greater demand than it can fill. Second, because the 2,000 CMA graduates are, by and large, unusually competent and influential, the program's influence is vastly multiplied. Third, CM A staff have deepened their own appreciation of how antisexist work relates to larger social issues.

Madunagu is aware that educating boys and young men about sexism and fostering critical thinking skills can appear threatening to some. He says,
"O bviously, oppression and power are very central to what we are talking about in CMA. In this country, many believe that you are either oppressed or oppressor. . . . You are standing on that person, or that person stands on you. ... . But to stand side by side, we don't know how."

CMA has deliberately stood apart from organized politics, in spite of-or perhaps precisely because of-Madunagu's history. For an organization working with boys, becoming overtly partisan could be perceived as a political threat, and might lead to CMA's being shut down by the state authorities. Even so, men who might be connected to security forces come to CIINSTRID's library regularly and sit down quietly to observe activities.

Asked what most people think of his work, Madunagu simply laughs: "They think it's a very odd thing that I am doing. This has confirmed my oddity in their minds! But at the same time, the respect is very high." 


\section{Chall lenges}

CM A's rapid growth in largely uncharted territory has not come without difficulties. Interviews with Madunagu, the field officers, and the CMA boys revealed a range of thorny issues-pedagogic, institutional, and political.

\section{Developing the Field Officers}

Often, the field officers are evolving along with their students, and many are still "coming into that knowledge." Some still tend to revert occasionally to a traditional didactic approach, rather than open dialogue.

\section{Addressing Difficult Topics}

CMA staff and field officers report that some topics are particularly difficult to tackle during discussions or in teacher training. Madunagu feels that they need to prepare better materials on these issues. These knotty topics are discussed below.

\section{Religion and the Role of Women}

CMA staff report that boys from devout families often have problems reconciling what they have been told in their religious practice with the idea of gender equality. ${ }^{4}$ In fact, in questionnaires administered to boys at the beginning of the program, the majority of respondents asserted that the man is the head of the family because that is what the Bible says. Such religious teachings support prevailing social norms, and therefore seem incontrovertibly "true" to many of the boys. $O$ ne boy claimed that men have multiple partners because "the Bible says that a man can marry 500 women."

Many of the boys' views on sexuality, masturbation, abstinence, and abortion are heavily influenced by religious teachings, but CMA insists on pluralism as the guiding principle. Program content is entirely secular, and arguments based on religious texts are not admissible in discussions. Some boys have left CMA because they could not reconcile their religious beliefs with CMA teachings, and, according to the reports in counseling records, continuing participants seem to be struggling with the dissonance. Igwe Dermot explained that some boys wish they could discuss what they learn at CMA with their parents, but feel they cannot raise certain issues, notably sexuality, because of their parents' religious beliefs.

\section{M asculinity}

The boys I interviewed had not reflected explicitly on the social definition of masculinity and its pitfalls from a personal or societal point of view. They were not able to say much about what pressures they experience as boys per se, what they don't like about being boys, or how they may suffer at the hands of other boys and men. Paul Awah reported that, in some discussions he has led, boys have remarked upon some of the ways in which the norms of masculinity affect them adversely. They mention, for example, that men have to go to war and men suffer political assassinations. But he admits that their analysis is not fully developed, because "boys are not ready to state that being boys causes them problems."

\section{Blaming the Victim of Sexual Violence}

Staff members told me that many boys

\footnotetext{
${ }^{4}$ In Eastern Nigeria, Christianity and traditional religions predominate.
} 
still blame the rape victim or think that girls and women, in most circumstances, are just "there for the taking." Therefore, they have problems understanding and condemning marital rape or even incest. Whether a man can be raped by a woman also remains a troubling question among some boys. The underlying assumption is that women are somehow to be blamed for uncontrolled male sexual desire and that women "force men to have sex."

\section{Sexual Health}

Topics such as sexually transmitted infections, sexual experiences, reproductive physiology, and negotiation of contraception still carry a measure of taboo among some of the field officers, who hesitate to discuss sexuality and sexual health in depth. This hesitation seems particularly to affect Level I teach- ers. At CM A's request, GPI has undertaken field officer and staff training on these subjects, but apparently, more training is needed to ensure quality and consistency of content.

\section{The Social Costs of Non conformity}

Speaking out against such commonly accepted behaviors as female genital cutting or domestic violence has placed some boys and CM A staff in complicated and conflicted situations. CMA is still seeking ways to improve the curriculum to prepare boys for this challenge, for example, by helping them develop more effective intervention styles. They also hope to strengthen the counseling service to better support boys who face repercussions for their outspokenness.

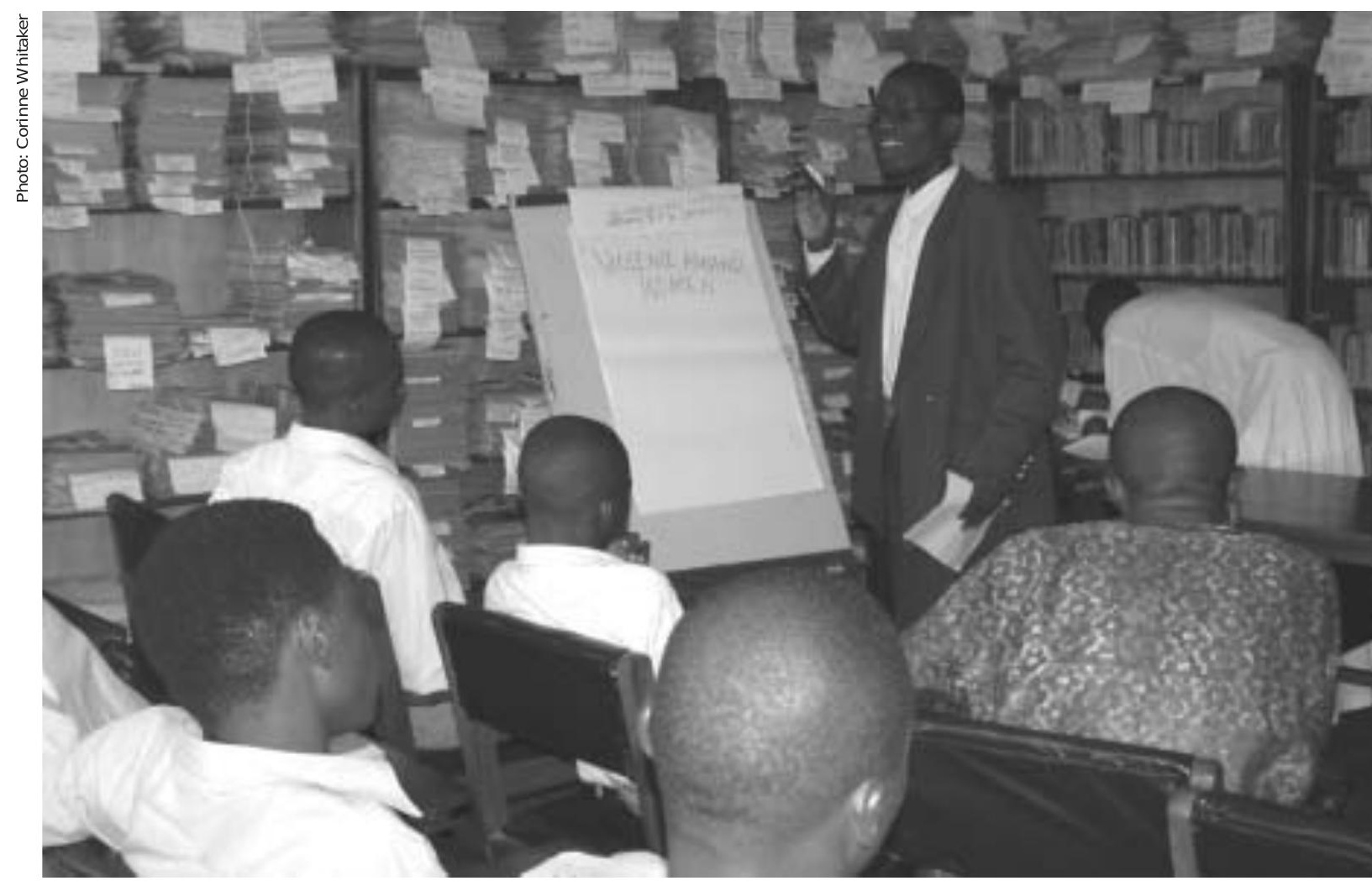

Many boys still blame the rape victim and have difficulties understanding or condemning marital rape. 


\section{Institutional Challenges}

$M$ any of the institutional issues faced by CMA are common to settings where poverty and political instability are prevalent, whereas other challenges relate directly to CMA's philosophy and method.

\section{Dropouts}

Continuation rates are high in light of the duration of the commitment required for participation in the program. In some schools, however, as many as 25 percent of Level I boys drop out, and absenteeism is also common. The difficulty some boys have with the content of the discussion is clearly a factor. Some boys are absent or drop out because their parents are behind on school fees. CMA staff also report that some boys cannot sit still in the discussions because they are hungry after school. Packets of biscuits are now handed out in some schools. Some Level II boys complain that the small stipend CMA provides for transportation to the monthly discussions is too low.

\section{Parental Views}

Although most parents are apparently pleased with their sons' participation in CMA, some parents are suspicious about the program, particularly at first (see section above entitled "What About Behavior?"). CMA is developing mechanisms to overcome parental skepticism. Madunagu invited one father who thought CMA would "corrupt" his son to come to CIINSTRID and speak with him; now the father is happy that his son is going to the CIIN STRID library instead of "roaming." Staff also find that the CMA publications such as The Male Adolescent reassure most parents that their son is not joining one of the cults or secret societies flourishing in Nigerian secondary schools. CMA believes that housing the program in schools gives it credibility and reduces parental concerns, but can place schools in the middle; the staff therefore organize orientation sessions in schools where parents express their fears to the principal that CMA will teach their sons about having sex.

\section{Program Management}

From the beginning, CMA boys have played central roles in shaping, and even running, the program. Graduates of CMA joined the part-time staff of the program early on and helped to develop the curriculum. For CMA, placing adolescent participation at the center of its work has clearly contributed to the program's appeal and effectiveness. However, Madunagu initially gave some of these adolescents responsibilities and power they were not equipped to handle, which has resulted in staff infighting and a number of thefts.

Madunagu realizes that staff selection at CMA and CIINSTRID has been relatively haphazard; many were offered employment simply because they needed financial support. Some hired for this reason have become strong staff who have stayed with the organization, but friction exists between staff who are committed to CMA and those who are there primarily because they need money.

Permanent CM A staff and M adunagu himself describe the management of CMA as "turbulent." This situation is perhaps to be expected from an organization that promotes critical thinking, open discussions, and nonhierarchical relationships. Yet some of this turbulence also comes from Madunagu's own style of leadership; he favors selfcriticism and is demanding in terms of commitment, probably unrealistically so. Although he is determined to main- 
tain a central role for boys in the program, Madunagu is also hoping to develop a more stable professional team for core management.

\section{Salaries and Turnover}

Nigerians face crushing poverty, and the standard of living of the middle class has decreased dramatically. Many CMA employees support other family members, and tuition fees are a constant problem. The young CMA graduates on staff, in particular, are under pressure from their families to contribute more and more to their families' budgets. Because CIINSTRID is a nongovernmental organization that receives money from oyibo (white people), and because it offers its programs free of charge, the perception is that its resources must be inexhaustible.

As a leftist thinker and activist now deeply engaged with foreign donors and their expectations regarding CMA, Madunagu faces philosophical and managerial dilemmas. It pains him to retell stories of staff who exclaim, when asking for raises and personal loans: "But you say you are a socialist!"

Remuneration of field officers appears to be an ongoing issue. Despite regular increases, they constantly clamor for more. Madunagu detests being an employer and discussing money. $\mathrm{He}$ reports that the current salaries for field officers are twice what he planned to give them when he wrote the most recent budget. $\mathrm{He}$ is concerned that GPI facilitators earn two or three times less, and probably work three times harder, which is a considerable paradox for two organizations committed to gender equality.

Some Level I field officers find difficulty combining their regular teaching job with CMA work, which requires training and preparation. Some do not turn up for the weekly sessions with the boys. Turnover of field officers in the schools is moderate: 0 ne field officer in ten leaves every year, on average.

\section{Scaling U p}

Scaling up will continue to be a challenge, given the intense investment that is required to train and oversee field officers and staff. Moreover, because

\section{Madunagu is concerned that facilitators at the Girls' Power Initiative earn two or three times less-and probably work three times harder-than CMA facilitators, a considerable paradox for two organizations committed to gender equality.}

CM A deliberately works only with boys who are leaders, expansion cannot proceed by enrolling more and more participants in each school; rather, it must reach more schools and towns. Madunagu also feels that the program needs to strengthen field-officer training and teaching materials before it can expand further. Finally, the management style that Madunagu favors is not well suited to expansion; a fair amount of staff energy is expended on repeated internal reorganization, changes in committee structures, and staff meetings to discuss problems.

\section{E valuation}

As mentioned above, the program has used two principal tools to evaluate the impact of CMA on boys: questionnaires and home visits. Baseline questionnaires gauge boys' knowledge and opinions at 
the beginning of Levels I and II. Midterm and end-of-year questionnaires are used to evaluate changes in knowledge and stated opinions. Some students may provide nonsexist answers on the questionnaires without having changed their true beliefs and behaviors. To date, the questionnaires have not been analyzed systematically. The answers are simply copied out in a notebook by a staff member. I read many of them, and the gestalt of the answers seems to indicate that the boys' knowledge and stated opinions have indeed become less sexist over the course of the program. In the project year 2001-02, when I visited, staff were unsure whether they would administer the end-of-year questionnaire and were considering conducting home visits instead.

CMA staff who are graduates of the program make home visits and report on them. The reports are of limited value, however. O ften, no one is home who knows the boy and can answer questions about him, so the CMA staff often come back empty-handed. In any case, the questions asked by the CMA staff do not appear to be specific enough to generate useful answers. To the extent that comments were recorded, they tended to indicate that the boy had improved his behavior. Staff recognize that they will need to train the interviewers and establish a system of specific appointments with parents if they want to continue using this method of evaluation.

Field officers are also evaluated informally, both by staff who occasionally observe sessions, as well by students, whose comments are sought concerning field officers' effectiveness as discussion leaders.

\section{CENTRID CENTRE FOR RESEARCH. INFORMATION AND DOCUMENTATION}

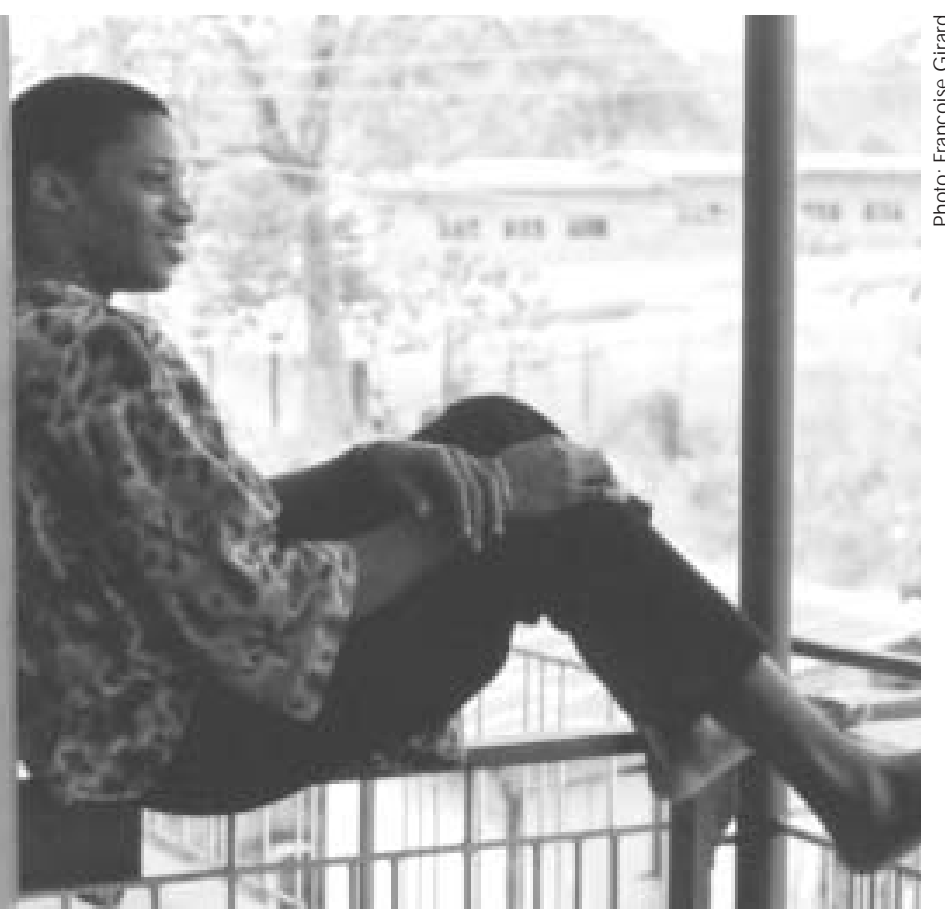




\section{Conclusion and Lessons Learned}

Working with boys is now considered a necessity for those who hope to achieve gender equality and ensure sexual and reproductive health and rights. CMA shows that it is possible to work with boys on issues of sexism and gender-based injustice, even in a context of pronounced inequality. Consolidating the program's gains and addressing its weaknesses will take time. In a corner of southeastern Nigeria, however, "conscientization" of male adolescents is clearly more than just an idea, and CM A's experience already provides rich lessons for anyone designing programs intended to reach adolescent boys and young men:

- Boys crave knowledge. They want to learn how to express themselves, to think critically, and to make sense of their world. Substantial and continuous training, along with appropriate reference materials, must be provided to group leaders to foster this process.

- Many boys aged 14 and older can conceptualize ideas and come to understand the oppression of women by analogy, but the learning process is arduous because they have not experienced gender oppression themselves.

- Not all boys can fully grasp the concepts of gender equality, but they will, nevertheless, adjust their behavior to the social norms set by their peers.

- For programs trying to reach particularly bright and motivated boys, academic enhancement opportunities may be at least as appealing as other auxiliary program offerings. Of course, sessions must still be interactive and fun, and discussion leaders must use a variety of techniques to impart content.

- Programs must guard against promoting another form of patriarchy, by which boys "protect" girls and women.

- Effective evaluation methods must be developed to assess changes in social norms and power dynamics at the community level.

- Helping boys think critically and expanding their knowledge about power and sexism may be more effective than a focus on health in bringing about behavioral change-including those behaviors affecting health. Program designers may want to consider such a paradigm shift. 
El proyecto Concienciación de Varones Adolescentes (CMA, por sus siglas en inglés) de Nigeria fue fundado en 1995 por Eddie Madunagu. Parte del Instituto Internacional de Investigación, Información y D esarrollo de Calabar (CIINSTRID), el CMA involucra a varones adolescentes en grupos de diálogo semanales. En contraste con la mayoría de los programas diseñados para muchachos adolescentes, los cuales optan por intervenciones de corto plazo con el fin de prevenir enfermedades y embarazos no deseados, el CM A emplea un modelo de largo plazo (por lo menos un año), enfocado en combatir el machismo y promover el pensamiento crítico.

El plan de discusiones del programa cubre temas como la opresión relacionada al género, los derechos sexuales, la violencia relacionada al género, el poder dentro de la familia, las responsabilidades del varón en las relaciones, la salud sexual, los derechos humanos, y la equidad. Para facilitar el cuestionamiento y el análisis de supuestos entre los participantes, se les enseña aspectos de lógica y debate verbal, y se enfatizan el diálogo socrático y los juegos de roles. El CMA recluta muchachos que muestran características de inteligencia y liderazgo social en sus escuelas. Las discusiones se llevan a cabo en escuelas, y el CMA capacita a profesores cuidadosamente seleccionados para conducir las sesiones.

Aunque el programa fue diseñado para durar un año, muchos profesores manifestaban que no podían completar el intenso plan de estudios durante este plazo, y muchos participantes querían seguir reuniéndose después del año escolar. El CMA agregó programas de extensión. Actualmente, muchos muchachos permanecen en el programa durante un año adicional (reuniéndose una vez por mes), y algunos han continuado hasta tres años. Estos grupos avanzados utilizan un plan de estudios más ambicioso que incluye actividades en la comunidad, como organizar debates públicos e intervenir en contra de comportamientos machistas. También se ha inaugurado un programa especial para varones en la universidad.

Además de los grupos de discusión, el CMA ofrece la excelente biblioteca del CIINSTRID y un servicio de consejería para problemas que requieren apoyo individualizado.
Durante los primeros seis años, 2.000 muchachos completaron el programa de CMA; unos 700 más se anotaron para participar en 2002. Aunque el CMA no ha realizado evaluaciones sistemáticas, entrevistas con participantes, sus compañeras escolares, padres, y líderes comunitarios indican que el programa provocó cambios importantes en las actitudes y comportamientos de los varones, tanto en la escuela como en el hogar. Las reacciones de los padres han sido positivas, en parte porque el CMA orienta a los padres sobre el programa, pero también porque les gusta la dimensión académica del plan de estudios. Según algunos profesores, los muchachos del CMA están influyendo en las normas de comportamiento en la escuela, multiplicando el efecto del programa. Uno de los 'egresados' del CMA resumió lo que aprendió del siguiente modo:

¿No quieres un mundo de paz, un mundo donde hay equidad? ¿Q uieres un mundo donde nuestros padres le pegan a nuestras madres? . . . la cultura es dinámica, no es estática. No estamos invalidando la cultura. Hay aspectos de nuestra cultura que son malos. Peleamos contra esos aspectos.

El programa sigue enfrentando ciertos desafíos. Las convicciones religiosas de algunos de los participantes están en conflicto con el contenido del programa. Se requiere mucha capacitación y seguimiento para asegurar que los profesores se sientan cómodos discutiendo temas delicados. El hecho de que el programa busca trabajar con muchachos con perfil de líder significa que para crecer el programa tendrá que extenderse geográficamente. Y el programa todavía está encontrando cómo manejar temas como la contratación de personal y la evaluación programática.

Las experiencias del CMA demuestran que es posible cambiar las actitudes y los comportamientos de varones jóvenes en cuanto a la equidad de género, y desarrollar facultados de pensamiento crítico a la misma vez. Cuando el objetivo es cambiar el comportamiento, incluso los comportamientos que afectan la salud sexual y reproductiva, este enfoque de largo plazo, basado en la equidad, podría ser más efectivo que uno basado principalmente en la salud. 


\section{Résumé en Françaís}

Le projet nigérian « Conscientiser les adolescents de sexe masculin » (CMA), fondé en 1995 par Eddie Madunagu, fait partie de l'Institut international de Calabar pour la recherche, l'information et le développement (CIIN STRID). Les jeunes garçons se réunissent au sein de groupes de discussion hebdomadaires. Le modèle proposé par CMA, soit un programme de longue durée axé sur le développement de la pensée critique et la lutte contre le sexisme, se distingue de la plupart des programmes offerts aux adolescents de sexe masculin, qui mettent l'accent sur des activités de courte durée visant à prévenir maladies sexuellement transmissibles et grossesses.

Le programme traite d'une vaste gamme de sujets, tels qu'oppression et violence basées sur le genre, droits sexuels, relations de pouvoir au sein de la famille, responsabilité dans le cadre de relations d'amitié ou d'amour, santé sexuelle, droits de la personne, et égalité. II inclut également une formation en expression orale et en logique, et ses méthodes pédagogiques privilégient le dialogue socratique et les jeux de rôles. CMA choisit des étudiants talentueux et qui font déjà figure de leaders. Les discussions se tiennent dans les écoles et sont animées par des professeurs choisis et formés par CMA.

Bien qu'ils aient conçu CM A comme un programme d'un an, les dirigeants de CM A constatèrent vite que certains professeurs n'arrivaient pas à traiter toute la matière et que nombre de garçons souhaitaient continuer les rencontres à la fin de l'année. CMA ajouta une deuxième année avec rencontres mensuelles pour répondre à la demande. Certains participants poursuivent même une troisième année. Ces groupes plus avancés bénéficient d'un programme exigeant, qui fait place à l'activisme communautaire, comme l'intervention sur la place publique pour mettre en question des comportements sexistes, et à l'organisation de débats. Un groupe de discussion a également été mis sur pied à l'université.

CMA offre aussi I'usage de l'excellente bibliothèque de CIINSTRID à tous ses participants, et un service d'assistance sociopsychologique aux garçons ayant besoin de conseils personnalisés.
2000 jeunes hommes ont complété le programme avec succès au cours des six premières années; 700 participants étaient inscrits en 2002. Bien que CMA n'ait pas encore procédé à une évaluation systématique de ses résultats, des entrevues menées auprès de participants, compagnes de classe, parents, et dirigeants de groupes de base révèlent des changements significatifs dans les comportements et attitudes des garçons, tant à l'école qu'à la maison. Les parents sont bien disposés envers CMA, notamment parce que CMA les a familiarisés avec le contenu du programme, et à cause du caractère académique de celui-ci. De plus, les professeurs expliquent que les participants donnent le ton à l'ensemble de l'école, augmentant ainsi l'effet multiplicateur de CMA. Un jeune "diplômé » de CMA résume ainsi ce qu'il a appris:

Veux-tu un monde de paix? Veux-tu un monde où règne l'équité? $\mathrm{O} u$ préfères-tu vraiment un monde où nos pères battent nos mères? ... La culture, c'est quelque chose de dynamique, pas quelque chose de statique. N ous ne cherchons pas à jeter à terre notre culture. Mais il y a des aspects de notre culture qui sont négatifs. C'est contre cela que nous nous battons.

Des défis continuent de se poser. Certains des garçons ont de la difficulté à concilier le contenu du programme et leurs croyances religieuses. Une formation poussée et un suivi assidu sont requis pour que les professeurs traitent avec aisance des sujets « délicats ». Puisque le programme ne recrute que les garçons les plus prometteurs, I'expansion des activités suppose une expansion à d'autres écoles. CM A est aussi aux prises avec diverses questions de gestion, comme l'évaluation du programme et l'organisation du personnel.

L'expérience de CMA au Nigéria montre qu'il est possible de changer les attitudes et comportements des garçons sur la question du sexisme, ainsi que de développer leurs aptitudes à la pensée critique. II se peut qu'un programme de longue durée, basé sur l'égalité de genre, soit en fait mieux en mesure de modifier les comportements des adolescents-y compris en matière de santé sexuelle et reproductive-qu'un programme axé principalement sur les questions de santé. 


\section{A bout the Authors}

Gary Barker is director of Instituto PRO M U NDO, a Brazilian organization working with men and boys.

Françoise $\mathbf{G}$ irard is an independent consultant and former Senior Program Officer for International Policy at the International Women's H ealth Coalition.

\section{Production Staff}

Editor: Debbie Rogow

Research and editorial assistant:

Michelle Skaer

Project editor: Karen Tweedy-H olmes

D esigner: Mike Vosika

Translators: Paul Constance (Spanish) and Françoise Girard (French)

\section{Advisory Group}

$\begin{array}{ll}\text { Delia Barcelona } & \text { Ann Leonard } \\ \text { Gary Barker } & \text { Ann McCauley } \\ \text { Carmen Barroso } & \text { Liz McGrory } \\ \text { Judith Bruce } & \text { Manisha M ehta } \\ \text { Batya Elul } & \text { Suellen M iller } \\ \text { Susana Galdos } & \text { Nancy N ewton } \\ \text { Kirrin Gill } & \text { Saumya Ramarao } \\ \text { Françoise Girard } & \text { Julie Reich } \\ \text { Nicole Haberland } & \text { Ann Starrs } \\ \text { Judith F. Helzner } & \text { Cynthia Steele } \\ \text { Katherine Kurz } & \text { Gilberte Vansintejan } \\ \text { Laura Laski } & \text { Margot Zimmerman }\end{array}$

CIIN STRID/CM A

90B Goldie Street

P.O. Box 915

Calabar Nigeria

tel: 087-234704

fax: 087-238615

e-mail: ciinstrid@hyperia.com

We invite your comments on Q uality/Calidad/Q ualité. If you would like to be included on our mailing list, please send an e-mail to: qcq@popcouncil.org. M ost past editions are available online at $<w w w$. popcouncil.org/publications/qcq/default.htm>. The following are also available in print; single or multiple copies may be ordered by e-mail:

Celebrating Mother and Child on the Fortieth Day: The Sfax Tunisia Postpartum Program (English only), no. 1, 1989.

Man/Hombre/Homme: Meeting Male Reproductive Health Care Needs in Latin America (English, Spanish), no. 2, 1990.

The Bangladesh Women's Health Coalition (English only), no. 3, 1991.

Gente Joven/Young People: A Dialogue on Sexuality with Adolescents in Mexico (English, Spanish), no. 5, 1993.

The Coletivo: A Feminist Sexuality and Health Collective in Brazil (English, Portuguese, Spanish), no. 6, 1995.

Doing More with Less: The Marie Stopes Clinics of Sierra Leone (English only), no. 7, 1995.
Introducing Sexuality within Family Planning: Three Positive Experiences from Latin America and the Caribbean (English, Spanish), no. 8, 1997.

U sing COPE to Improve Q uality of Care: The Experience of the Family Planning Association of Kenya (English, Spanish), no. 9, 1998.

Alone You Are Nobody, Together We Float: The Manuela Ramos Movement (English, Spanish), no. 10, 2000.

From Patna to Paris: Providing Safe and $\mathrm{Hu}$ mane Abortion (English only), no. 11, 2001.

U niversal Sexuality Education in Mongolia: Educating Today to Protect Tomorrow (English only), no. 12, 2002.

What about Us? Bringing Infertility into Reproductive Health Care (English only), no. 13, 2002. 
Q/C/Q No. 14

calité/Quality /Calidad/Quali 